\title{
The geochemical composition of sediment as a proxy of provenance and weathering intensity: a case study of Southwest Nigeria's Coastal Creeks
}

\author{
Olusegun Adebayo Phillips ${ }^{1}$, \\ Adenike Omotayo Falana², Adegboyega Joel Adebayo ${ }^{2}$ \\ ${ }^{1}$ Central Research Laboratory, The Polytechnic, Ibadan; Nigeria; e-mail: egbenzuaagaga@gmail.com \\ ${ }^{2}$ Geology Department, The Polytechnic, Ibadan; Nigeria
}

(C) 2017 Authors. This is an open access publication, which can be used, distributed and reproduced in any medium according to the Creative Commons CC-BY 4.0 License requiring that the original work has been properly cited.

Received: 11 June 2017; accepted: 6 December 2017

\begin{abstract}
The study of the geochemical composition of sediments was undertaken to evaluate the degree of weathering and appraise the relative proportion of mafic and felsic rock materials being transported from source to sink. Thirty-three surface sediment samples collected from the creeks were used for particle size and chemical analyses. An inductively coupled plasma-Mass Spectrometer was used to determine the elemental composition of the sediments. The clay dominated Yewa and western Badagry creeks gave evidence of higher average concentrations of $\mathrm{Ni}, \mathrm{Sr}, \mathrm{Y}, \mathrm{Nb}, \mathrm{Sc}, \mathrm{Co}, \mathrm{V}$, and $\mathrm{Th}$ than the eastern end of segment of Badagry Creek. The data generated from elemental ratios such as $\mathrm{Al}_{2} \mathrm{O}_{3} / \mathrm{TiO}_{2}, \mathrm{TiO}_{2} / \mathrm{Zr}$ and binary plots of $\mathrm{Th} / \mathrm{Sc}-\mathrm{Cr} / \mathrm{Sc}$, Th-Sc, $\mathrm{Y} / \mathrm{Ni}-\mathrm{Cr} / \mathrm{V}, \mathrm{TiO}_{2}-\mathrm{Zr}$ and ICV-CIA (index of compositional variability against chemical index of alteration) showed that source sediments are composed of upper and lower crustal compositions. Also, the creeks were marked by their variation in terms of the proportion of felsic and mafic components. For instance, Yewa and western Badagry creeks are more enriched in mafic constituents, whereas the enrichment of felsic materials is significant at the eastern end of Badagry Creek. Inferring from the chemical index of alteration and plagioclase index of alteration (PIA), the Yewa and western Badagry creeks have been moderately to intensely weathered and incipient weathering was identified in the eastern end of Badagry Creek.
\end{abstract}

Keywords: Badagry Creek, Yewa Creek, elemental ratios, provenance, weathering

\section{INTRODUCTION}

Due to the difficulty that may arise from the separation of individual minerals, most provenance studies employ chemical methods. The geochemical composition of clastic sediments has been widely used for the determination of the provenance and tectonics of source area (Tripathi \& Rajamani 1999, 2007, Singh \& Rajamani 2001). Chemical constituents of sediments, specifically relatively immobile major and trace elements transported in particulate form e.g. Al, Fe, Ti, Th, $\mathrm{Sr}, \mathrm{Ba}, \mathrm{Zr}, \mathrm{Nb}$ and $\mathrm{Sc}$, have been found to be reliable indicators of the source (Taylor \& McLennan 1985). The performance of these elements in provenance studies is dependent on the assumption that they behave in a similar manner throughout the entire process of sediment formation, mostly by weathering and subsequent transport and deposition. Similarly, the bulk chemical changes that take place during weathering and the relative mobility of group elements belonging to alkali and 
alkaline earth elements have been used to quantify the weathering history recorded in sedimentary rocks, primarily to understand past climatic conditions (Nesbitt \& Young 1984).

The use of major elements as a dominant technique for provenance studies is quite rare, perhaps because of their post-depositional mobility. Various bivariate plots of major elements used to study turbidite mudstones and sandstones from New Zealand did not discriminate these samples (Roser \& Korsch 1988). Nonetheless, these authors were able to largely eliminate the overlap between sample populations with the help of cross-plotting discriminant functions calculated from the weight percentage of major element constituents. Major element chemistry has yielded success in the determination of the integrated weathering history of the source area (Oliva et al. 2003, Yang et al. 2004, Viers et al. 2009, Bouchez et al. 2011a).

According to Lee (2002), trace elements such as $\mathrm{Ni}$ and $\mathrm{Cr}$ are abundant in ultramafic and mafic rocks but rare in rocks with a more felsic composition and hence are good indicators of ophiolitic sources. Also useful is $\mathrm{Zr}$, which is more abundant in felsic rocks but its concentration in sediments is also controlled by their grain size (Grygar \& Popelka 2016). The implication is that plots of $\mathrm{Ni} / \mathrm{Zr}$ or $\mathrm{Cr} / \mathrm{Zr}$ can be used to reveal the proportion of mafic material in the source area. However, weathering and diagenesis can alter the concentration of $\mathrm{Ni}$, so it is preferable to use less soluble elements than $\mathrm{Ni}$ in provenance studies. Because $\mathrm{Th}$, Sc, and $\mathrm{Cr}$ are quite insoluble and are transported almost exclusively in detritus, they are good indicators of sedimentary provenance. Notwithstanding, a fraction of all elements is removed in solution, and the rate of loss increases with time, the dissolution rate of elements such as $\mathrm{Th}, \mathrm{Sc}$, and the REE is small in most exogenic environments (Balashov et al. 1964, Nesbitt 1979, Davies 1980). Mechanical weathering plays a major role in grainsize reduction. Feldspars grains are the most easily cleaved, e.g. along twin planes and are thus prone to breakage during high energy transport. Chemical weathering on the other hand, causes the reduction of grain size by replacement of sand and silt size primary mineral grains with clay-size metal oxides and clay minerals (Faure 1991) and by the incremental reduction of the size of individual grains during congruent dissolution reaction (Lasaga 1984).

Several chemical indices have been proposed to quantify the intensity of weathering. The most traditional is the chemical index of alteration (CIA) defined as $\left[\mathrm{Al}_{2} \mathrm{O}_{3} /\left(\mathrm{Al}_{2} \mathrm{O}_{3}+\mathrm{CaO}^{*}+\mathrm{K}_{2} \mathrm{O}+\right.\right.$ $\left.\left.+\mathrm{Na}_{2} \mathrm{O}\right)\right] \times 100$ where $\mathrm{CaO}^{*}$ is $\mathrm{CaO}$ in silicate fraction only (Fedo et al. 1995). A better discrimination of parent rock types would include Fe and $\mathrm{Mg}$ which are critical constituents of ultrabasic rocks. These constituents are considered in a measure called the index of compositional variability (ICV) proposed by Cox et al. (1995): $\left[\mathrm{CaO}+\mathrm{K}_{2} \mathrm{O}+\right.$ $\left.+\mathrm{Na}_{2} \mathrm{O}+\mathrm{Fe}_{2} \mathrm{O}_{3}(t)+\mathrm{MgO}+\mathrm{MnO}+\mathrm{TiO}_{2} / \mathrm{Al}_{2} \mathrm{O}_{3}\right]$, where $\mathrm{Fe}_{2} \mathrm{O}_{3}(t)$ represents total iron oxides and $\mathrm{CaO}$ includes all sources of $\mathrm{Ca}$. In addition to CIA and ICV, plagioclase index of alteration (PIA) proposed by Fedo et al. (1995) will be considered in this study since plagioclase is abundant in silicate rocks and dissolves relatively rapidly: $\mathrm{PIA}=\left[\left(\mathrm{Al}_{2} \mathrm{O}_{3}-\mathrm{K}_{2} \mathrm{O}\right) /\left(\mathrm{Al}_{2} \mathrm{O}_{3}+\mathrm{CaO}^{*}+\right.\right.$ $\left.\left.+\mathrm{Na}_{2} \mathrm{O}-\mathrm{K}_{2} \mathrm{O}\right)\right] \times 100$ where $\mathrm{CaO}^{*}$ is $\mathrm{CaO}$ residing only in silicate fraction.

The goals of this study were to employ sediment chemistry to infer degree of chemical weathering in the source area and simultaneously to determine the provenance of sediments of Badagry and Yewa creeks from the southwest Nigeria coast. Such information may help to establish the composition of rocks exposed on the surface; elucidate the soluble elements that are not fractionated during the weathering process, giving a reliable estimate of their abundance. Achieving these goals also brings better insights into the rate of $\mathrm{CO}_{2}$ consumption by means of silicate weathering as a part of the long-term control of atmospheric $\mathrm{CO}_{2}$ :

$$
\begin{array}{ccc}
\mathrm{CaAl}_{2} \mathrm{Si}_{2} \mathrm{O}_{8}+2 \mathrm{CO}_{2}+ & & \mathrm{Al}_{2} \mathrm{Si}_{2} \mathrm{O}_{5}(\mathrm{OH})_{4}+ \\
+3 \mathrm{H}_{2} \mathrm{O} & +\mathrm{Ca}^{2+}+2 \mathrm{HCO}_{3}^{-} \\
\text {anorthite } & & \text { kaolinite } \\
2 \mathrm{NaAlSi}_{3} \mathrm{O}_{8}+2 \mathrm{CO}_{2}+ & & \mathrm{Al}_{2} \mathrm{Si}_{4} \mathrm{O}_{10}(\mathrm{OH})_{2}+ \\
+6 \mathrm{H}_{2} \mathrm{O} & \rightarrow & +2 \mathrm{Na}^{+}+2 \mathrm{HCO}_{3}^{-}+ \\
& & +2 \mathrm{H}_{4} \mathrm{SiO}_{4} \\
\text { albite } & & \text { montmorillonite }
\end{array}
$$


It is expected that where chemical weathering is intense, the rate of consumption of atmospheric $\mathrm{CO}_{2}$ will be high (Berner \& Berner 1997, Edmond \& Huh 1997). This study is the first of its kind in the southwest Nigeria coast as there is no available literature on the source area weathering of recent sediments in this region.

\section{STUDY AREA}

On a regional view, the study area has five geomorphic units (Adegoke et al. 1980). These units are (i) the abandoned beach ridge complex, made up of series of elongated sand ridges, and commonly situated on both sides of the lagoon and creeks in alternation with mud-filled depressions; (ii) the coastal creeks and lagoons trending in parallel to the coastline, separated from the sea by the active barrier beach complex; (iii) the vegetated swamp flats north of Badagry but without vegetation cover in the coastal area of Lagos; (iv) the forested river flood plain with thick vegetation cover; and (v) the active barrier beach complex, well-washed light brown shelly sand, immediately along the shore. According to Ibe (1988), the barrier beach-lagoon complex extends eastward for about $200 \mathrm{~km}$ from the border between $\mathrm{Ni}$ geria and Benin republics to the western limit of the Transgressive mud coast. It was further stated that the morphology has been largely determined by coastal dynamics and drainage. The barrier lagoon complex is backed by the Badagry Creek, Lagos Lagoon and numerous creeks whose only connection to the sea is through the Commodore Channel in Lagos.

Badagry Creek flows across the boundaries of the Federal Republic of Nigeria and the Bénin Republic between the longitudes $2^{\circ} 42^{\prime} \mathrm{E}$ and $3^{\circ} 29^{\prime} \mathrm{E}$ and latitudes $6^{\circ} 23^{\prime} \mathrm{N}$ and $6^{\circ} 28^{\prime} \mathrm{N}$. The sources of water into this creek include Lagune de Porto-Novo in Benin Republic; and in the Nigeria, Yewa and Owo rivers, and Ologe and Lagos lagoons. The creek is shallow with an average water depth of $3.5 \mathrm{~m}$ in addition to the irregular topography being displayed.

The Yewa Creek which was also investigated lies within the latitudes $6^{\circ} 26^{\prime} \mathrm{N}$ and $6^{\circ} 34^{\prime} \mathrm{N}$ and longitudes $2^{\circ} 50^{\prime} \mathrm{E}$ and $2^{\circ} 55^{\prime} \mathrm{E}$. This creek has a shallow water depth with an average of $1.0 \mathrm{~m}$ at the centre, reaching a maximum of $3.0 \mathrm{~m}$ where it opens into Porto-Novo creek (the western end of Badagry) and Badagry Creek (eastern end). The Porto-Novo creek at the western end within the limit of the Nigeria border is referred to as the western end of Badagry Creek and is where eight sediment samples were collected (B1-B8).

\section{MATERIALS AND METHODS}

Thirty-three surficial sediment samples were collected from the Yewa and Badagry creeks with the aid of a $30 \mathrm{~cm} \times 30 \mathrm{~cm}$ Ekman grab sampler. The sample location coordinates were taken using an eTrex Garmin Global Positioning System (GPS). Three hundred grams of each air-dried samples were wet-sieved using $2 \mathrm{~mm}$ mesh to remove gravel size particles and percentages of size fractions were calculated. The dried samples of coarse sand to clay fractions obtained were well homogenized by coning and quartering. A fifty-gram portion of each of these samples were used for the standard pipetting method of Gale \& Hoare (1991) in order to separate sand, silt and clay contents.

Approximately $5 \mathrm{~g}$ each of pulverized sample $(<75 \mu \mathrm{m})$ was used to prepare press pellets and litho-geochemical whole rock fusion was performed. The method involved the sample digestion by lithium metaborate / tetraborate fusion $\left(\mathrm{LiBO}_{2} / \mathrm{Li}_{2} \mathrm{~B}_{4} \mathrm{O}_{7}\right)$. An aliquot of the sample i.e. $0.2 \mathrm{~g}$ was weighed, mixed with $1.5 \mathrm{~g}$ lithium metaborate / lithium tetraborate flux in a graphite crucible and fused in a furnace set at $980^{\circ} \mathrm{C}$ for 30 minutes. The cooled bead was dissolved in 5\% $\mathrm{HNO}_{3}$ (American Chemical Society i.e. ACS grade nitric acid diluted in demineralized water). This procedure was taken for the sediment and basement rock samples collected in the study area. Inductively Coupled Plasma combined with a mass spectrometer (ICP-MS) was used for the analysis of elements. Although ICP-MS is expensive and requires the sample to be completely dissolved, it shows very low detection limits for a great number of elements including trace elements of utmost interest with too low concentrations for the 
determination by X-ray fluorescence (XRF). The sample digestion and spectrometric analysis were made in the Acme Analytical Laboratory (Vancouver), Canada, and report submitted with certificate number VAN 13002288.1 on the 6th of August, 2013.

\section{RESULTS AND DISCUSSION}

The composition of major and trace elements of the sediments sampled at Yewa and Badagry creeks, southwestern Nigeria sector of the Gulf of Guinea coast are presented in Tables 1-3.

Table 1

The percentage composition of elemental oxides constituting the sediments of Yewa and Badagry Creeks, Southwest Nigeria

\begin{tabular}{|c|c|c|c|c|c|c|c|c|c|c|c|}
\hline Sample Id & $\mathrm{SiO}_{2}$ & $\mathrm{Al}_{2} \mathrm{O}_{3}$ & $\mathrm{Fe}_{2} \mathrm{O}_{3}$ & $\mathrm{MgO}$ & $\mathrm{CaO}$ & $\mathrm{Na}_{2} \mathrm{O}$ & $\mathrm{K}_{2} \mathrm{O}$ & $\mathrm{TiO}_{2}$ & $\mathrm{P}_{2} \mathbf{O}_{5}$ & $\mathrm{MnO}$ & $\mathrm{Cr}_{2} \mathrm{O}_{3}$ \\
\hline B1 & 35.29 & 16.12 & 8.40 & 1.36 & 3.85 & 0.32 & 1.08 & 0.96 & 0.18 & 0.13 & 0.014 \\
\hline B2 & 39.45 & 18.56 & 9.41 & 1.58 & 1.04 & 0.87 & 1.37 & 1.13 & 0.21 & 0.09 & 0.015 \\
\hline B3 & 39.38 & 17.65 & 9.21 & 1.52 & 1.54 & 0.57 & 1.27 & 1.09 & 0.22 & 0.10 & 0.014 \\
\hline B4 & 42.86 & 18.25 & 9.55 & 1.50 & 1.00 & 0.51 & 1.49 & 1.18 & 1.20 & 0.09 & 0.016 \\
\hline B5 & 42.71 & 18.52 & 8.95 & 1.39 & 1.07 & 0.73 & 1.38 & 1.15 & 0.19 & 0.09 & 0.017 \\
\hline B6 & 41.91 & 15.90 & 12.96 & 1.44 & 2.44 & 0.50 & 1.24 & 0.94 & 0.17 & 0.14 & 0.014 \\
\hline B7 & 40.93 & 17.74 & 9.91 & 1.55 & 3.18 & 0.38 & 1.29 & 1.07 & 0.15 & 0.14 & 0.015 \\
\hline B8 & 43.27 & 12.78 & 9.67 & 1.17 & 1.91 & 0.31 & 1.01 & 0.84 & 0.15 & 0.16 & 0.012 \\
\hline B9 & 75.11 & 3.92 & 7.38 & 0.49 & 3.39 & 0.38 & 0.63 & 0.46 & 0.12 & 0.17 & 0.005 \\
\hline B10 & 81.59 & 4.64 & 2.83 & 0.43 & 2.19 & 1.01 & 0.78 & 0.78 & 0.07 & 0.08 & 0.005 \\
\hline B11 & 41.25 & 15.03 & 9.10 & 1.40 & 4.07 & 0.42 & 1.20 & 1.01 & 0.15 & 0.18 & 0.012 \\
\hline B12 & 48.45 & 11.44 & 7.40 & 1.19 & 1.92 & 0.78 & 1.06 & 1.21 & 0.11 & 0.21 & 0.011 \\
\hline B13 & 34.62 & 12.09 & 12.00 & 0.79 & 0.78 & 0.27 & 0.45 & 0.62 & 0.26 & 0.05 & 0.013 \\
\hline B14 & 75.63 & 5.66 & 4.47 & 0.50 & 3.46 & 0.68 & 0.96 & 0.78 & 0.10 & 0.15 & 0.007 \\
\hline B15 & 65.17 & 10.33 & 6.13 & 0.79 & 1.74 & 0.57 & 1.14 & 0.81 & 0.12 & 0.15 & 0.01 \\
\hline B16 & 68.23 & 7.58 & 3.70 & 0.75 & 3.01 & 1.21 & 0.75 & 0.53 & 0.10 & 0.04 & 0.007 \\
\hline B17 & 82.67 & 4.84 & 3.07 & 0.40 & 1.26 & 0.73 & 0.88 & 0.63 & 0.07 & 0.09 & 0.007 \\
\hline B18 & 74.69 & 5.33 & 8.87 & 0.65 & 1.04 & 0.36 & 0.71 & 0.41 & 0.09 & 0.08 & 0.007 \\
\hline B19 & 76.48 & 6.34 & 3.77 & 0.53 & 2.56 & 0.55 & 0.82 & 0.57 & 0.07 & 0.10 & 0.008 \\
\hline B20 & 39.24 & 16.96 & 8.29 & 1.61 & 0.71 & 1.82 & 1.10 & 0.92 & 0.23 & 0.16 & 0.014 \\
\hline B21 & 44.72 & 16.14 & 7.15 & 1.48 & 0.81 & 1.87 & 1.08 & 7.92 & 0.22 & 0.06 & 0.014 \\
\hline B22 & 40.15 & 17.10 & 8.24 & 1.60 & 0.79 & 1.77 & 1.07 & 0.92 & 0.24 & 0.16 & 0.014 \\
\hline $\mathrm{Y} 1$ & 31.01 & 10.16 & 11.48 & 0.61 & 0.6 & 0.11 & 0.28 & 0.49 & 0.39 & 0.06 & 0.011 \\
\hline $\mathrm{Y} 2$ & 35.43 & 13.46 & 8.85 & 0.71 & 1.74 & 0.14 & 0.30 & 0.62 & 0.18 & 0.03 & 0.013 \\
\hline Y3 & 35.74 & 12.24 & 10.67 & 0.47 & 1.12 & 0.11 & 0.30 & 0.63 & 0.38 & 0.04 & 0.013 \\
\hline Y4 & 34.71 & 12.68 & 11.68 & 0.95 & 0.64 & 0.33 & 0.53 & 0.65 & 0.19 & 0.05 & 0.012 \\
\hline Y5 & 35.42 & 11.57 & 11.19 & 0.58 & 0.81 & 0.13 & 0.33 & 0.58 & 0.32 & 0.05 & 0.011 \\
\hline Y6 & 81.49 & 2.30 & 3.23 & 0.14 & 0.51 & 0.07 & 0.12 & 0.46 & 0.09 & 0.02 & 0.005 \\
\hline Y7 & 34.28 & 11.32 & 10.04 & 0.84 & 0.82 & 0.40 & 0.41 & 0.55 & 0.24 & 0.05 & 0.011 \\
\hline Y8 & 28.90 & 10.29 & 10.54 & 0.75 & 0.94 & 0.20 & 0.27 & 0.46 & 0.15 & 0.06 & 0.011 \\
\hline Y9 & 33.66 & 13.03 & 11.34 & 1.04 & 0.57 & 0.34 & 0.61 & 0.68 & 0.17 & 0.05 & 0.011 \\
\hline Y10 & 40.96 & 14.02 & 13.78 & 1.42 & 2.56 & 0.41 & 1.01 & 0.89 & 0.17 & 0.16 & 0.012 \\
\hline Y11 & 39.98 & 14.01 & 12.06 & 1.24 & 0.77 & 0.39 & 0.93 & 0.81 & 0.16 & 0.09 & 0.013 \\
\hline $\begin{array}{c}\text { UCC } \\
\text { (Taylor \& } \\
\text { McLennan } \\
\text { 1985) }\end{array}$ & 66.00 & 15.20 & 4.50 & 2.20 & 4.20 & 3.90 & 3.40 & 0.50 & 0.17 & - & - \\
\hline
\end{tabular}


Table 2

Trace element concentrations (ppm) of the analyzed sediments

\begin{tabular}{|c|c|c|c|c|c|c|c|c|c|c|c|c|}
\hline Sample Id & $\mathrm{Fe}$ & Mn & $\mathrm{Ba}$ & $\mathrm{Ni}$ & $\mathrm{Sr}$ & $\mathbf{Y}$ & $\mathrm{Nb}$ & Sc & $\mathbf{Z r}$ & Co & V & Th \\
\hline $\mathrm{B} 1$ & 43700 & 903 & 326 & 37 & 198 & 28 & 17 & 15 & 123 & 24 & 54 & 7 \\
\hline B2 & 50500 & 639 & 348 & 48 & 96 & 31 & 20 & 17 & 147 & 25 & 61 & 7 \\
\hline B3 & 47200 & 644 & 351 & 37 & 109 & 30 & 19 & 16 & 135 & 22 & 58 & 8 \\
\hline $\mathrm{B} 4$ & 50300 & 653 & 378 & 39 & 98 & 34 & 27 & 17 & 188 & 26 & 65 & 9 \\
\hline B5 & 49400 & 592 & 369 & 35 & 91 & 33 & 23 & 17 & 165 & 24 & 65 & 11 \\
\hline B6 & 76300 & 1008 & 370 & 36 & 136 & 33 & 22 & 15 & 227 & 33 & 57 & 9 \\
\hline B7 & 49200 & 1011 & 369 & 37 & 153 & 30 & 24 & 16 & 209 & 23 & 52 & 8 \\
\hline B8 & 52200 & 1109 & 332 & 37 & 178 & 25 & 18 & 12 & 429 & 24 & 37 & 6 \\
\hline B9 & 50000 & 1143 & 317 & 10 & 140 & 15 & 9 & 4 & 658 & 25 & 47 & 9 \\
\hline $\mathrm{B} 10$ & 23800 & 297 & 248 & 10 & 146 & 15 & 9 & 4 & 995 & 9 & 12 & 3 \\
\hline B11 & 46700 & 1118 & 393 & 25 & 182 & 35 & 24 & 14 & 355 & 27 & 51 & 9 \\
\hline B12 & 20700 & 555 & 324 & 24 & 120 & 38 & 20 & 12 & 1541 & 13 & 22 & 3 \\
\hline B13 & 71700 & 353 & 191 & 28 & 75 & 21 & 17 & 10 & 136 & 21 & 24 & 6 \\
\hline B14 & 18600 & 606 & 348 & 10 & 168 & 20 & 14 & 5 & 1164 & 9 & 14 & 1 \\
\hline B15 & 22400 & 647 & 379 & 10 & 133 & 22 & 14 & 9 & 511 & 11 & 19 & 3 \\
\hline B16 & 23400 & 701 & 186 & 10 & 131 & 15 & 8 & 6 & 393 & 11 & 21 & 3 \\
\hline B17 & 36500 & 1001 & 307 & 10 & 122 & 13 & 2.5 & 4 & 752 & 15 & 16 & 1 \\
\hline B18 & 15800 & 365 & 253 & 10 & 78 & 12 & 2.5 & 6 & 302 & 6 & 11 & 1 \\
\hline B19 & 29200 & 363 & 278 & 10 & 142 & 14 & 6 & 5 & 438 & 11 & 29 & 4 \\
\hline B20 & - & - & 220 & 38 & 92 & 27 & 13 & 14 & 352 & - & - & - \\
\hline B21 & - & - & 229 & 35 & 95 & 26 & 12 & 13 & 475 & - & - & - \\
\hline B22 & - & - & 219 & 31 & 94 & 26 & 18 & 14 & 352 & - & - & - \\
\hline $\mathrm{Y} 1$ & 71100 & 423 & 158 & 10 & 68 & 19 & 10 & 8 & 128 & 26 & 21 & 6 \\
\hline $\mathrm{Y} 2$ & 49500 & 248 & 166 & 32 & 103 & 25 & 15 & 10 & 176 & 32 & 42 & 7 \\
\hline Y3 & 57700 & 325 & 206 & 24 & 72 & 23 & 16 & 9 & 186 & 25 & 28 & 7 \\
\hline $\mathrm{Y} 4$ & 62900 & 391 & 188 & 31 & 72 & 21 & 13 & 10 & 123 & 19 & 24 & 6 \\
\hline Y5 & 66100 & 351 & 186 & 10 & 69 & 20 & 10 & 9 & 157 & 28 & 22 & 7 \\
\hline Y6 & 21100 & 140 & 72 & 10 & 24 & 8 & 2.5 & 2 & 715 & 28 & 9 & 2 \\
\hline Y7 & 57700 & 324 & 161 & 21 & 75 & 20 & 11 & 9 & 108 & 23 & 25 & 5 \\
\hline Y8 & 70300 & 405 & 142 & 24 & 78 & 21 & 26 & 9 & 104 & 26 & 26 & 5 \\
\hline Y9 & 66800 & 398 & 190 & 25 & 74 & 23 & 17 & 11 & 127 & 26 & 26 & 7 \\
\hline Y10 & 78500 & 1104 & 323 & 26 & 140 & 29 & 18 & 13 & 536 & 31 & 41 & 7 \\
\hline Y11 & 72500 & 690 & 284 & 21 & 90 & 27 & 15 & 13 & 205 & 29 & 43 & 8 \\
\hline
\end{tabular}

Table 3

Elemental ratios and calculated weathering indices for the studied sediments

\begin{tabular}{|c|c|c|c|c|c|c|c|c|c|c|c|}
\hline Sample Id & $\mathbf{M}^{*}$ & $\mathbf{V} /(\mathbf{V}+\mathbf{N i})$ & $\mathbf{N i} / \mathbf{C o}$ & $\mathbf{A l}_{2} \mathbf{O}_{3} / \mathbf{T i O}_{2}$ & $\mathbf{T i O}_{2} / \mathbf{Z r}$ & $\mathbf{N b} / \mathbf{S c}$ & $\mathbf{T h} / \mathbf{S c}$ & $\mathbf{Z r} / \mathbf{S c}$ & $\mathbf{C I A}$ & PIA & ICV \\
\hline B1 & 0.20 & 0.59 & 1.54 & 16.79 & 0.0078 & 2.47 & 0.47 & 8.20 & 66.10 & 67.8 & 1.00 \\
\hline B2 & -0.01 & 0.56 & 1.92 & 16.42 & 0.0077 & 2.82 & 0.41 & 8.65 & 81.20 & 85.8 & 0.83 \\
\hline B3 & 0.02 & 0.61 & 1.68 & 16.19 & 0.0081 & 2.31 & 0.50 & 8.44 & 79.40 & 83.5 & 0.87 \\
\hline B4 & 0.00 & 0.63 & 1.50 & 15.47 & 0.0063 & 2.29 & 0.53 & 11.06 & 92.80 & 99.3 & 0.84 \\
\hline B5 & -0.04 & 0.65 & 1.46 & 16.10 & 0.007 & 2.06 & 0.65 & 9.71 & 81.60 & 86.3 & 0.80 \\
\hline B6 & 0.01 & 0.61 & 1.09 & 16.91 & 0.0041 & 2.40 & 0.60 & 15.13 & 72.00 & 75.0 & 1.24 \\
\hline B7 & 0.20 & 0.58 & 1.61 & 16.58 & 0.0051 & 2.31 & 0.50 & 13.06 & 70.40 & 73.0 & 0.99 \\
\hline
\end{tabular}


Table 3 cont.

\begin{tabular}{|c|c|c|c|c|c|c|c|c|c|c|c|}
\hline Sample Id & $\mathbf{M}^{*}$ & $\mathrm{~V} /(\mathrm{V}+\mathrm{Ni})$ & $\mathrm{Ni} / \mathrm{Co}$ & $\mathrm{Al}_{2} \mathrm{O}_{3} / \mathrm{TiO}_{2}$ & $\mathrm{TiO}_{2} / \mathrm{Zr}$ & $\mathrm{Nb} / \mathrm{Sc}$ & Th/Sc & $\mathrm{Zr} / \mathrm{Sc}$ & CIA & PIA & ICV \\
\hline B8 & 0.21 & 0.50 & 1.54 & 15.21 & 0.002 & 3.08 & 0.50 & 35.75 & 73.00 & 76.3 & 1.18 \\
\hline B9 & 0.25 & 0.82 & 0.40 & 8.52 & 0.0007 & 2.50 & 2.25 & 164.5 & 35.30 & 33.2 & 3.29 \\
\hline B10 & -0.02 & 0.55 & 1.11 & 5.95 & 0.0008 & 2.50 & 0.75 & 248.75 & 42.30 & 40.9 & 1.75 \\
\hline B11 & 0.27 & 0.67 & 0.93 & 14.88 & 0.0028 & 1.79 & 0.64 & 25.36 & 62.50 & 64.0 & 1.16 \\
\hline B12 & 0.31 & 0.48 & 1.85 & 9.45 & 0.0008 & 2.00 & 0.25 & 128.42 & 66.90 & 69.5 & 1.20 \\
\hline B13 & -0.42 & 0.46 & 1.33 & 19.50 & 0.0046 & 2.80 & 0.60 & 13.60 & 87.50 & 90.3 & 1.24 \\
\hline B14 & 0.40 & 0.58 & 1.11 & 7.26 & 0.0007 & 2.00 & 0.20 & 232.80 & 40.80 & 39.2 & 1.94 \\
\hline B15 & 0.35 & 0.66 & 0.91 & 12.75 & 0.0016 & 1.11 & 0.33 & 56.78 & 67.20 & 70.5 & 1.10 \\
\hline B16 & 0.36 & 0.68 & 0.91 & 14.30 & 0.0013 & 1.67 & 0.50 & 65.50 & 48.50 & 48.4 & 1.32 \\
\hline B17 & 0.32 & 0.62 & 0.67 & 7.68 & 0.0008 & 2.50 & 0.25 & 188.00 & 53.10 & 53.9 & 1.46 \\
\hline B18 & 0.25 & 0.52 & 1.67 & 13.00 & 0.0014 & 1.67 & 0.17 & 50.33 & 63.70 & 66.8 & 2.27 \\
\hline B19 & -0.02 & 0.74 & 0.91 & 11.12 & 0.0013 & 2.00 & 0.80 & 87.60 & 50.20 & 50.3 & 1.40 \\
\hline B20 & - & - & - & 18.43 & 0.0026 & 2.71 & - & 25.14 & 77.50 & 80.9 & 0.86 \\
\hline B21 & - & - & - & 2.04 & 0.0167 & 2.69 & - & 36.54 & 75.70 & 78.8 & 1.26 \\
\hline B22 & - & - & - & 18.59 & 0.0026 & 2.21 & - & 25.14 & 77.60 & 80.9 & 0.85 \\
\hline Y1 & -0.34 & 0.68 & 0.38 & 20.73 & 0.0038 & 1.25 & 0.75 & 16.00 & 94.10 & 96.7 & 1.34 \\
\hline $\mathrm{Y} 2$ & -0.41 & 0.57 & 1.00 & 21.71 & 0.0035 & 3.20 & 0.70 & 17.60 & 80.40 & 81.6 & 0.92 \\
\hline Y3 & -0.36 & 0.54 & 0.96 & 19.43 & 0.0034 & 2.67 & 0.78 & 20.67 & 88.20 & 90.1 & 1.09 \\
\hline Y4 & -0.32 & 0.44 & 1.63 & 19.51 & 0.0053 & 3.10 & 0.60 & 12.30 & 87.40 & 90.6 & 1.17 \\
\hline Y5 & -0.39 & 0.69 & 0.36 & 19.95 & 0.0037 & 1.11 & 0.78 & 17.44 & 90.10 & 92.4 & 1.18 \\
\hline Y6 & -0.29 & 0.47 & 0.36 & 5.00 & 0.0006 & 5.00 & 1.00 & 357.50 & 70.60 & 72.4 & 1.98 \\
\hline Y7 & -0.36 & 0.54 & 0.91 & 20.58 & 0.0051 & 2.33 & 0.56 & 12.00 & 84.90 & 87.4 & 1.16 \\
\hline Y8 & -0.35 & 0.52 & 0.92 & 22.37 & 0.0044 & 2.67 & 0.56 & 11.56 & 83.90 & 85.6 & 1.28 \\
\hline Y9 & -0.34 & 0.51 & 0.96 & 19.16 & 0.0054 & 2.27 & 0.64 & 11.55 & 87.60 & 91.2 & 1.12 \\
\hline Y10 & 0.03 & 0.61 & 0.84 & 15.75 & 0.0017 & 2.00 & 0.54 & 41.23 & 70.00 & 72.4 & 1.44 \\
\hline Y11 & -0.14 & 0.67 & 0.72 & 17.30 & 0.004 & 1.62 & 0.62 & 15.77 & 84.00 & 88.7 & 1.16 \\
\hline
\end{tabular}

\section{Effects of source rock on grain size composition}

The distribution of particle sizes in sediments was considered because of source rock effects on sediment composition. Characteristically, fine grained volcanic rocks produce sands with abundant aphanitic lithic fragments and few sand-sized mineral grains (Dickinson \& Suczek 1979, Dickinson 1985). Also, the ratio of coarse to fine clastic particles varies as a function of source rocks. Accordingly, Ruxton (1970) documented that the erosion products of mafic igneous rocks are dominated by labile silicate minerals, and basaltic rocks yield abundant fine-grained or glassy lithic materials. Ruxton (1970) also said that, on average, the weathering product of granitic rocks have a higher ratio of siliceous resistates to clay minerals than mafic or basaltic rocks and consequently the average grain size of such detritus is larger.
The geomorphological settings of Yewa, western and eastern Badagry creeks are as shown in the sampling location map of the study area (Fig. 1). Folk's (1954) triangular model of sediment classification revealed a wide range of sediment classes from sand through gravelly muddy sand to mud (Fig. 2) for Badagry Creek. This heterogenous nature was influenced by the complex hydrographic setting due to the network of rivers, creeks and lagoons contributing sediments to various locations of the creek. Yewa Creek is dominated by gravelly mud and gravelly sandy mud (Fig. 3). However, when contents of clay and silt were separated and the ternary plot of Shepard (1954) was employed, sand predominates with clayey sand, clay and sandy clay being well represented in decreasing order of abundance (Fig. 4) in Badagry creek. The resulting plot for Yewa Creek interpreted sandy clay $(>60 \%$ clay population $<80 \%$ ) as the main sediment class present with very few stations 
being dominated by more than $80 \%$ clay population (Fig. 5).

Grain-size effects and sediment provenance have a complementary influence on the chemical composition of fluvial sediments that is indeed difficult to distinguish (Grygar et al. 2016). The expectation is that insoluble trace elements will remain in association with clays and are transported from the outcrop by mechanical processes (McLennan 1989). As a result, their abundance in mudrocks generally reflects the composition of the source rocks (Cullers et al. 1974). This is evident at the clay dominated end of Badagry (B1B8) where $\mathrm{Ni}, \mathrm{Sr}, \mathrm{Y}, \mathrm{Nb}, \mathrm{Sc}, \mathrm{Zr}, \mathrm{Co}, \mathrm{V}$ and $\mathrm{Th}$ are of much higher values than the eastern half where the quantity of sand is significantly high (Tab. 2). Also, Yewa Creek which has mud dominated sediments, gave evidence of higher than average concentrations of trace elements (Y1-Y11) than the eastern half of Badagry Creek.

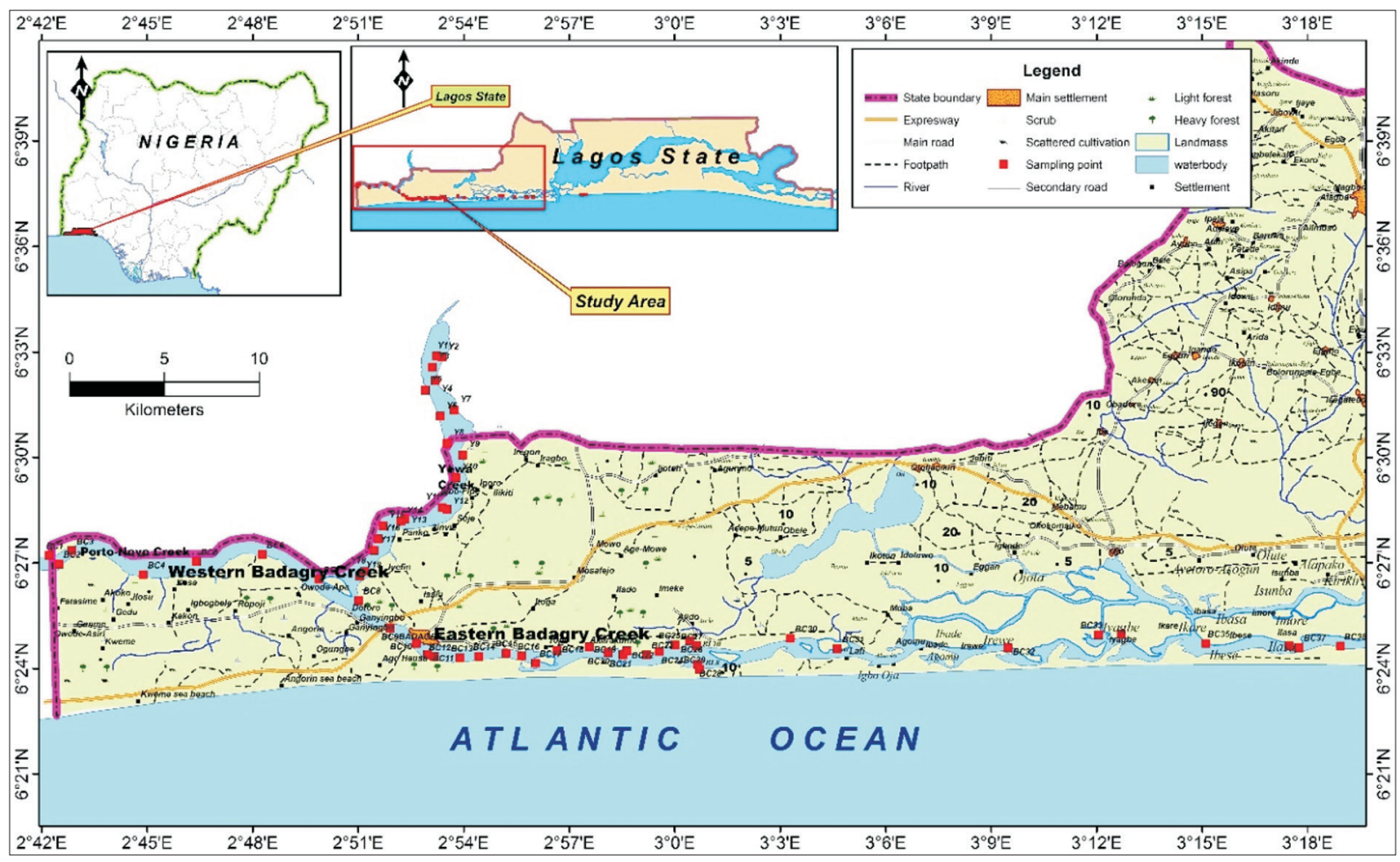

Fig. 1. The location map of Yewa and Badagry Creeks showing sampled stations

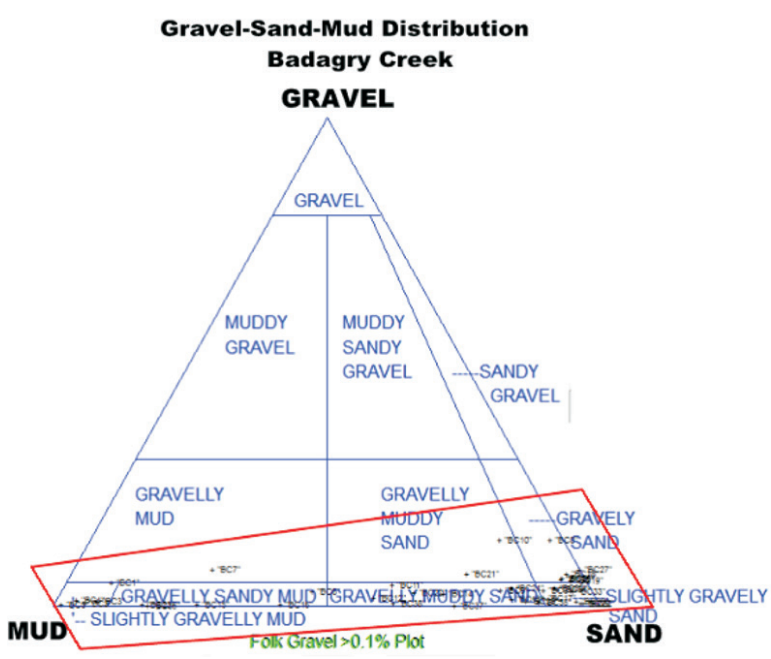

Fig. 2. Ternary plot of gravel-mud-sand distribution for the sediments of Badagry Creek

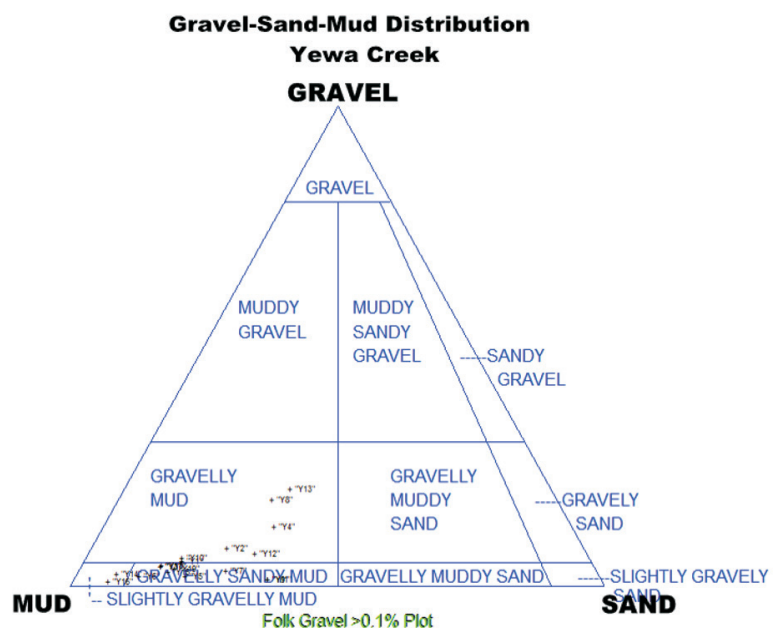

Fig. 3. Ternary plot of gravel-mud-sand distribution for the sediments of Yewa Creek 


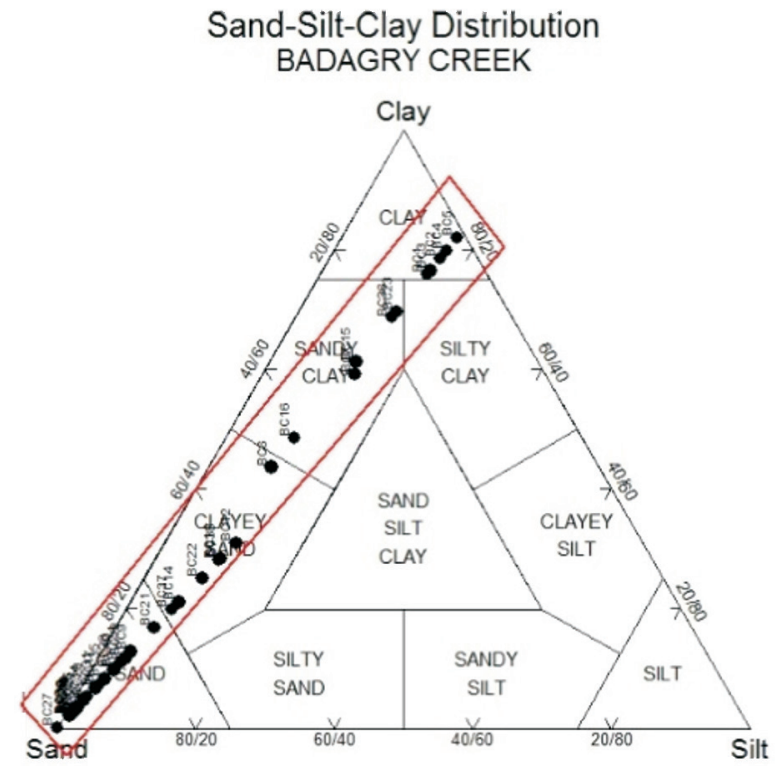

Fig. 4. Triangular diagram of clay-sand-silt distribution in the sediments of Badagry Creek

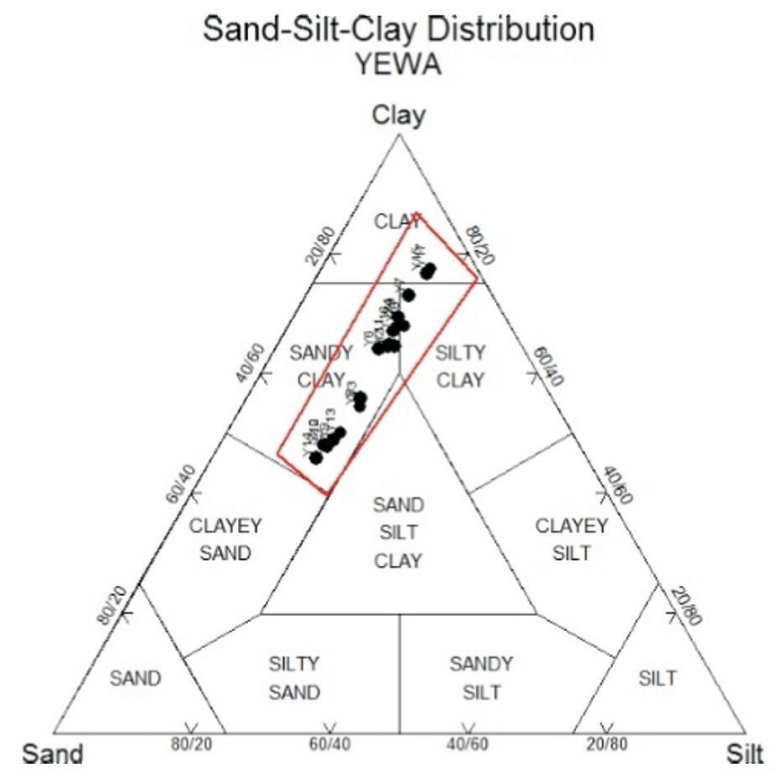

Fig. 5. Triangular diagram of clay-sand-silt distribution in the sediments of Yewa Creek

Progressive weathering facilitate depletion in primary silicate minerals constituting the sediments, these minerals are hydrolysed and cations and silicic acid are released into the dissolved load of the transporting fluid to produce new minerals, mainly very fine-grained clay minerals and oxides (Weaver 1989). The complete weathering of "average" basaltic rock could produce about $11 \%$ sand, $74 \%$ mud and $15 \%$ carbonate (Garrels \& Mackenzie 1971). Essentially, felsic rocks, which have a high proportion of quartz, produce significantly more sand than the average, and mafic rocks generate more mud. Grains produced or modified during weathering and erosion may be fractionated into different size populations in the course of transport although the effectiveness of this process depends on the fluvial environment. It is also important to note that, under most surface conditions, mafic minerals weather more rapidly than silicic minerals (Lasaga 1984), hence the population of sand grains becomes increasingly enriched in chemically stable phases, especially quartz. Consequently, by means of the documented evidences, it can be unequivocally inferred that the clay dominated Yewa and the western half of the Badagry creeks derived their sediments much more from the weathering of basic igneous rocks. Notwithstanding a long distance of transport which could cause massive grain size reduction by cleavages, the composition of quartz remains outstanding as this mineral possesses no plane of weakness. Regardless of the destructive nature of river transport, strained and weakened or even polycrystalline quartz grains are reduced to fine silt-size and sand-size grains ( $c f$. Mark 1978). It is therefore highly logical to infer that sediments in the eastern half of Badagry Creek are mostly derived from a felsic igneous source.

\section{Major and trace elements characteristics}

Yewa Creek has an inverted Y-shaped entrance, marking the area of demarcation between the short-western and long-eastern segments of Badagry Creek (Fig. 1). The overall chemical compositions of sediments indicated that the average silica contents are $39.23 \%, 40.78 \%$ and $60.57 \%$ for the Yewa, the western end of Badagry and the eastern end of Badagry creeks respectively. The complex hydrographic setting of the eastern end of Badagry Creek resulted in relatively wide variations in its chemical composition, especially $\mathrm{SiO}_{2}(34.62-82.67 \%)$. It is believed that the sediments of Yewa and Badagry creeks mainly originated from the crystalline basement complex of southwestern Nigeria. As a result, representative samples of the exposed rocks within the catchment area were taken and analysed for their chemical constituents. A simplistic evaluation of similarities and differences of constituents of these rocks, the creek sediments and upper continental crustal values (UCC of Taylor \& McLennan 1985) was made to offer insights into 
the provenance of the creek sediments. The chemical composition of UCC is widely regarded to be well known, and the values from Taylor \& McLennan (1985) are commonly cited. Of importance is the average chemical composition of basement rocks nearest to the study area which compares favourably with similar rocks in southwest Nigeria (Tab. 4). The comparison of the average composition of rocks in the catchment area provided evidence of the proportionate enrichment of alumina and impoverishment of silica in the sediments of the Yewa and the western end of Badagry creeks (Tab. 1). Conversely, enrichment of silica and depletion of alumina in sediments were shown in over $60 \%$ of sampled stations in the eastern end of Badagry Creek. A similar trend was shown based on the comparison of these creek sediments and UCC of Taylor \& McLennan (1985). However, considering the chemical composition of the amphibolite, it strongly contrasts with that of other basement rocks as there is relatively very low abundance of silica and high proportionate enrichment of $\mathrm{Al}_{2} \mathrm{O}_{3}$, $\mathrm{Fe}_{2} \mathrm{O}_{3}$ and $\mathrm{MgO}$. The weathering of this rock will definitely influence the average composition of the source area sediments believed to have been sourced from crustal rocks in the area. The mean values of $\mathrm{Na}_{2} \mathrm{O}$ and $\mathrm{K}_{2} \mathrm{O}$ for rocks in the study area are much higher than that in sediments of the creeks, whereas, $\mathrm{Fe}_{2} \mathrm{O}_{3}$ contents in sediments are much higher. Also, $\mathrm{MgO}$ and $\mathrm{CaO}$ are enhanced specifically in the sediments of the western end of Badagry Creek (Stations B1-B8) implying that the weathering of amphibolite, melanocratic components of banded-, granite- and migmatite gneisses contributed to the bulk composition of these sediments. Except for Ni, there is marked dissimilarity in the concentrations of the compatible and non-compatible elements between the basement rocks in the catchment area and the UCC values of Taylor \& McLennan (1985). It is therefore reasonable to restrict the comparison of the source area sediments to the rocks in the study area. Considering the average composition of basement rocks in the study area, the sediments of the Yewa and Badagry creeks are depleted in $\mathrm{Ba}$ and $\mathrm{Sr}$, whereas enrichment of $\mathrm{Ni}, \mathrm{Y}, \mathrm{Nb}, \mathrm{Sc}$ and $\mathrm{Zr}$ is revealed. Of all the rocks in the catchment area, amphibolite produced the chemical constituents in high resemblance of basaltic rocks (Tab. 4). The enrichment of compatible elements such as $\mathrm{Ni}$ and $\mathrm{Sc}$ attests to the fact that the weathering of basaltic rocks (e.g. amphibolite) also contributed to the sediments' composition. For instance, Ni has similar chemical behaviour to iron and magnesium, hence substitutes for them easily in Mg-Fe rich silicate minerals known to significantly constitute amphibolites.

Bouchez et al. (2011b) investigated the grain size control of suspended sediments geochemistry of the Amazon and documented the link between grain size distribution and the chemical composition of fluviatile sediments. It was concluded that higher values of $\mathrm{Al} / \mathrm{Si}$ are found in fine sediment while coarse samples are enriched in silica based on low values of $\mathrm{Al} / \mathrm{Si}$. A similar relationship exists in Yewa Creek, where relatively high values of $\mathrm{Al} / \mathrm{Si}$ can be inferred (Tab. 1) dominated by mud particles (Figs. 3, 5). Also, the sand dominated eastern end of Badagry Creek and mud prevalent western Badagry Creek (Figs. 2, 4) are marked by low and high values of $\mathrm{Al} / \mathrm{Si}$ respectively. Flood-tides influence the transport of sea sands into Lagos Lagoon through the connecting harbour. The back-water from the harbour in turn supplies fine sand to the eastern end of Badagry Creek, enabling the dilution of Al-rich components by quartz. This may be consequential to the high $\mathrm{Si}$ contents relative to a more mobile $\mathrm{Al}$ in stations $\mathrm{B} 9-\mathrm{B} 19$ of the eastern end of Badagry Creek. This contravenes the fact that $\mathrm{Si}$-rich sediments are less readily transported under the slow water conditions that characterizes this creek. Silicon content in sediments increases with a decrease in the concentration of soluble elemental oxides such as $\mathrm{Al}_{2} \mathrm{O}_{3}, \mathrm{~K}_{2} \mathrm{O}, \mathrm{MgO}$ and $\mathrm{P}_{2} \mathrm{O}_{5}$, indicating linear negative trends, whereas, $\mathrm{CaO}$ and $\mathrm{Na}_{2} \mathrm{O}$ denote a scattered distribution with $\mathrm{SiO}_{2}$ (Fig. 6). However, these major oxides exhibit linear positive trends with aluminium (Fig. 7) due to their chemical mobility potential. A unambiguous correlation of this kind was difficult to establish for the sediments of the Yewa Creek.

Using the ternary plot of Blatt et al. (1980) which considered the ferromagnesian, sodium and potassium contents, the investigated terrigenous sediments are classified as lithic arenite (Fig. 8). The applicability of $\mathrm{Na}_{2} \mathrm{O}-\mathrm{K}_{2} \mathrm{O}$ diagram (Figs. 9A, B) for the studied sediments yielded well enough to permit their quartz rich characteristics to be interpreted (Crook 1974). 


\begin{tabular}{|c|c|c|c|c|c|c|c|c|c|c|c|}
\hline 怘言 & تृ் & $N$ & تृ் & $\sim$ & ت் & $n$ & ¿্் & $\stackrel{\check{I}}{\check{\pi}}$ & $\stackrel{\check{I}}{\ddot{I}}$ & $m$ & $\vec{m}$ \\
\hline$\succ$ 㤩 & $\stackrel{\check{I}}{\dot{I}}$ & $\cong$ & تூّ & 6 & تேं & $\vec{n}$ & $\stackrel{\check{g}}{\ddot{g}}$ & $\stackrel{\check{J}}{\ddot{g}}$ & $\stackrel{\check{I}}{\ddot{I}}$ & $\approx$ & $\vec{n}$ \\
\hline 沄音 & تூّ & $\stackrel{\sim}{.}$ & $\stackrel{\check{I}}{\dot{I}}$ & $\stackrel{\sim}{~}$ & تُّ & $\stackrel{\sim}{~}$ & $\stackrel{ت}{\dot{I}}$ & $\stackrel{\check{J}}{\ddot{\pi}}$ & $\ddot{\check{g}}$ & $\stackrel{\sim}{~}$ & F \\
\hline 文五 & $\stackrel{\check{g}}{\dot{g}}$ & है & $\stackrel{\check{g}}{\dot{g}}$ & $\triangleq$ & $\stackrel{\check{g}}{\ddot{g}}$ & $\overrightarrow{\widehat{O}}$ & $\stackrel{\check{g}}{\ddot{g}}$ & $\stackrel{\check{g}}{\ddot{g}}$ & $\stackrel{\check{g}}{\ddot{g}}$ & $\overrightarrow{\widetilde{\Xi}}$ & 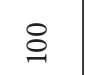 \\
\hline 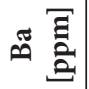 & $\stackrel{\check{g}}{\dot{x}}$ & $\begin{array}{l}\infty \\
\infty \\
\infty\end{array}$ & تூّ & 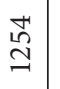 & تُ & $\overrightarrow{\stackrel{2}{\beth}}$ & ت் & تே் & $\stackrel{\check{I}}{\ddot{I}}$ & 홍 & กิ \\
\hline 完吾 & $\stackrel{\check{I}}{\dot{I}}$ & $\simeq$ & تृ் & in & تृ் & $\curvearrowright$ & $\ddot{\check{I}}$ & $\stackrel{\check{g}}{\ddot{\pi}}$ & تே் & $\stackrel{n}{\rightarrow}$ & $n$ \\
\hline के & $\stackrel{\ddot{g}}{\ddot{g}}$ & సે & $\stackrel{\check{J}}{\ddot{\pi}}$ & $\overrightarrow{\mathbb{N}}$ & $\stackrel{ت}{\ddot{\pi}}$ & ڤे & $\stackrel{\check{I}}{\ddot{n}}$ & $\stackrel{\check{g}}{\ddot{\pi}}$ & $\stackrel{\check{I}}{\ddot{I}}$ & $\overrightarrow{\underline{\sigma}}$ & हे \\
\hline $0^{\infty}+\infty$ & ت્்ّ & $\begin{array}{l}m \\
0 \\
0\end{array}$ & تُ & $\begin{array}{l}\tilde{O} \\
\stackrel{0}{0} \\
\dot{0}\end{array}$ & تூّ & 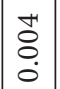 & ¿ே. & $\ddot{\check{g}}$ & ت্ & $\begin{array}{l}0 \\
\stackrel{0}{0} \\
0 \\
0\end{array}$ & $\begin{array}{l}+ \\
\stackrel{6}{0} \\
0\end{array}$ \\
\hline $0 \overline{0}$ & $\stackrel{\oplus}{=}$ & $\stackrel{n}{\stackrel{2}{+}}$ & 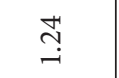 & $\stackrel{\Re}{\Omega}$ & $\stackrel{\infty}{\underset{+}{+}}$ & กֶ. & $\underset{+}{\overrightarrow{+}}$ & in & $\underset{+}{\stackrel{+}{+}}$ & $\begin{array}{l}0 \\
0 \\
0\end{array}$ & $\stackrel{9}{\rightrightarrows}$ \\
\hline $\begin{array}{l}0 \\
\tilde{z}^{\tilde{n}}\end{array}$ & તુ & $\begin{array}{l}\stackrel{0}{\circ} \\
\stackrel{\leftrightarrow}{+}\end{array}$ & $\underset{+}{F}$ & $\begin{array}{l}\stackrel{\leftrightarrow}{\alpha} \\
\stackrel{j}{*}\end{array}$ & $\underset{\text { i }}{\vec{j}}$ & $\begin{array}{c}\hat{i} \\
\end{array}$ & $\stackrel{\vec{i}}{i}$ & $\overrightarrow{\widetilde{N}}$ & $\begin{array}{l}\infty \\
\infty \\
\infty \\
\end{array}$ & $\stackrel{\hat{A}}{\mathrm{i}}$ & $\begin{array}{l}\hat{\sigma} \\
i\end{array}$ \\
\hline 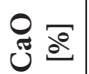 & ָึ & $\stackrel{\tilde{n}}{i}$ & $\stackrel{\tilde{n}}{\mathrm{n}}$ & ָે & $\stackrel{a}{e}$ & $\stackrel{\tilde{n}}{\mathrm{n}}$ & $\underset{\text { Ș }}{\text { i. }}$ & $\stackrel{\leftrightarrow}{\alpha}$ & 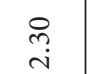 & $\stackrel{n}{\stackrel{n}{i}}$ & $\stackrel{9}{a}$ \\
\hline${ }_{2}^{\circ} \bar{a}$ & : & $\begin{array}{l}\text { זั } \\
\text { ș }\end{array}$ & $\begin{array}{l}\vec{b} \\
0\end{array}$ & 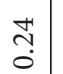 & $\stackrel{\widehat{N}}{\mathrm{i}}$ & $\stackrel{\text { ঙ̊ }}{\rightarrow}$ & $\stackrel{\stackrel{\leftrightarrow}{\rightarrow}}{\rightarrow}$ & 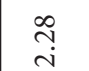 & ల్రి & ֵֵ. & $\stackrel{\infty}{\stackrel{\infty}{+}}$ \\
\hline $0^{n} \sigma^{\circ}$ & 苞 & ণั. & $\overline{7}$ & $\begin{array}{l}0 \\
\stackrel{2}{0} \\
0\end{array}$ & $\stackrel{\text { İ }}{0}$ & in & ণి & $\stackrel{\circ}{0}$ & $\stackrel{n}{\circ}$ & $\begin{array}{l}2 \\
\hat{n} \\
0\end{array}$ & $\stackrel{\text { : }}{\circ}$ \\
\hline 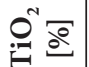 & $\stackrel{0}{\circ}$ & $\stackrel{\infty}{0}$ & กิ & $\begin{array}{l}m \\
0 \\
0\end{array}$ & $\begin{array}{l}R \\
0 \\
0\end{array}$ & ڤ̊. & in & $\stackrel{\substack{n \\
\dddot{m}}}{0}$ & $\stackrel{\infty}{0}$ & $\begin{array}{l}\infty \\
\infty \\
0 \\
0\end{array}$ & 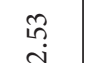 \\
\hline 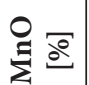 & $\tilde{o}$ & $\begin{array}{l}\tilde{O} \\
0 \\
0\end{array}$ & 苍 & $\begin{array}{l}\tilde{\delta} \\
0 \\
0\end{array}$ & $\begin{array}{l}\hat{0} \\
0\end{array}$ & $\begin{array}{l}\bullet \\
0 \\
0\end{array}$ & $\stackrel{7}{0}$ & $\stackrel{0}{\tilde{O}}$ & $\tilde{3}$ & o. & กี \\
\hline $0^{n} \overline{0}$ & $\stackrel{\infty}{\infty}$ & 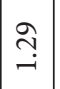 & in & $\stackrel{\infty}{=}$ & 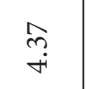 & $\begin{array}{l}\stackrel{0}{\circ} \\
\dot{\circ}\end{array}$ & $\stackrel{\leftrightarrow}{\stackrel{m}{+}}$ & 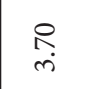 & $\stackrel{\infty}{\stackrel{\infty}{i}}$ & $\stackrel{\vec{m}}{m}$ & શે \\
\hline $0^{m} \frac{0}{a^{\infty}}$ & 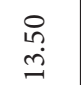 & $\begin{array}{l}\infty \\
\\
\end{array}$ & 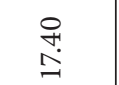 & 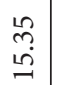 & 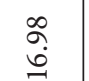 & $\begin{array}{l}\Delta \\
\stackrel{2}{n}\end{array}$ & $\begin{array}{l}\overrightarrow{\vec{n}} \\
\vec{n}\end{array}$ & $\begin{array}{l}\text { त̃ } \\
\text { ம் }\end{array}$ & $\stackrel{9}{\stackrel{0}{0}}$ & $\begin{array}{l}\text { Pे } \\
\text { in } \\
\end{array}$ & $\stackrel{\vec{N}}{\stackrel{\oplus}{\rightarrow}}$ \\
\hline $0^{N} \bar{s}$ & 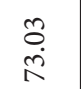 & $\begin{array}{l}\stackrel{8}{0} \\
\dot{1}\end{array}$ & 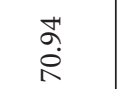 & $\begin{array}{l}\stackrel{0}{2} \\
20\end{array}$ & $\begin{array}{l}\stackrel{R}{\beta} \\
\text { రీ }\end{array}$ & $\begin{array}{c}0 \\
\dot{0} \\
0\end{array}$ & ஸิ & $\begin{array}{l}\vec{\infty} \\
\dot{b} \\
\dot{0}\end{array}$ & 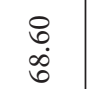 & $\begin{array}{l}\overrightarrow{1} \\
\dot{0} \\
0\end{array}$ & $\begin{array}{l}\stackrel{8}{\circ} \\
\dot{7}\end{array}$ \\
\hline \multirow{2}{*}{ 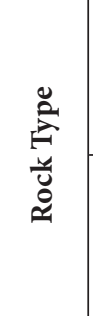 } & 怘 & 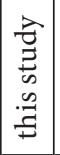 & 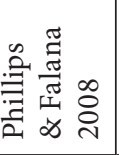 & 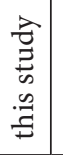 & 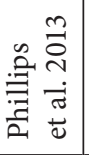 & 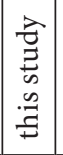 & 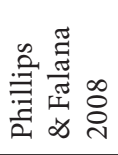 & 号 & $\begin{array}{l}\overrightarrow{\tilde{J}} \\
\frac{\vec{\sigma}}{\tilde{\sigma}} \\
\vec{H} \\
\vec{n}\end{array}$ & 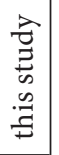 & \multirow[b]{2}{*}{ 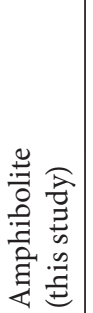 } \\
\hline & 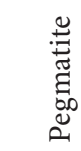 & & 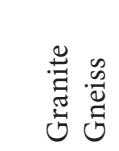 & & 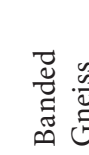 & & & 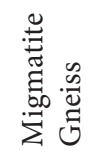 & & & \\
\hline
\end{tabular}



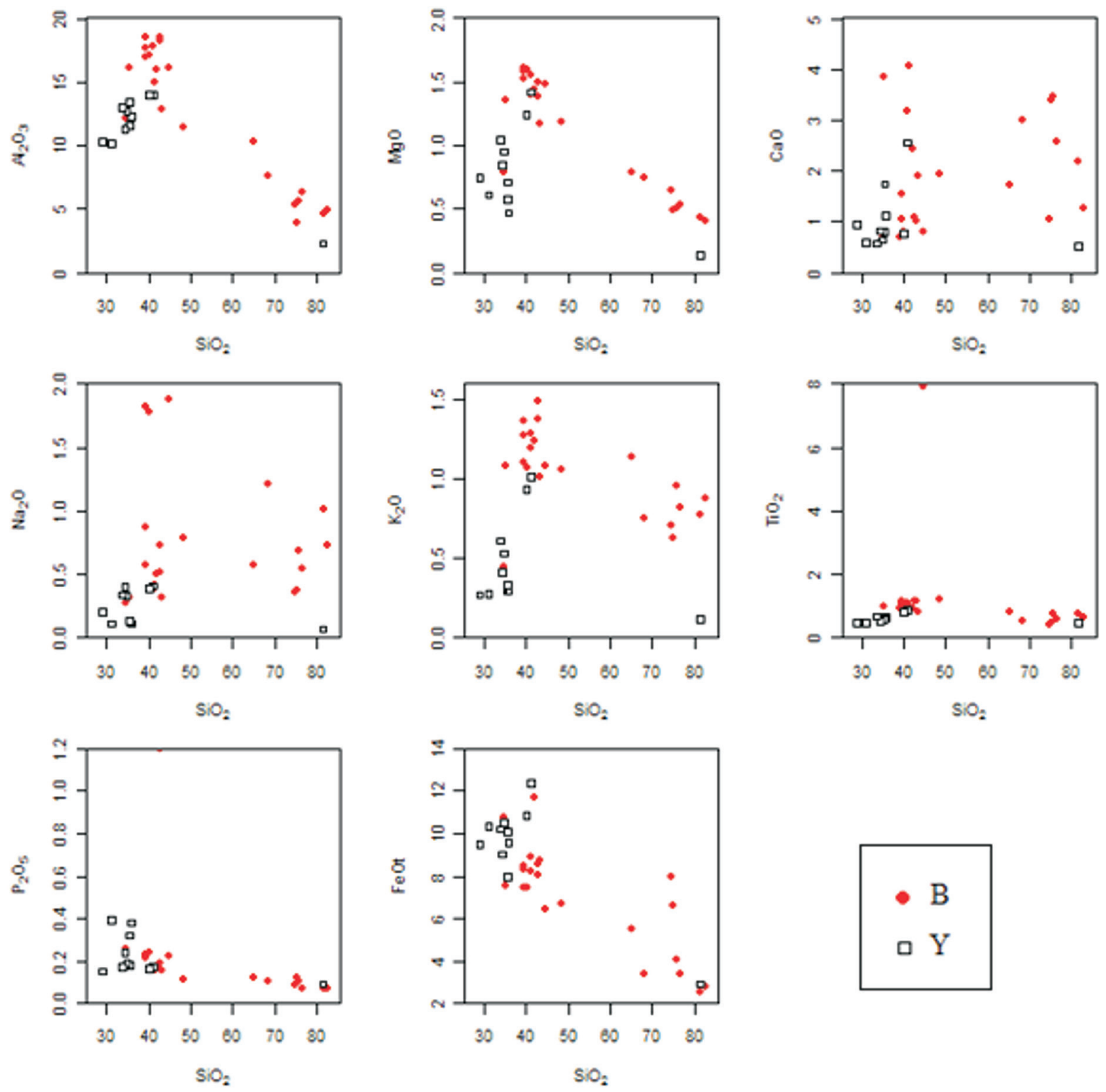

Fig. 6. Relationship between $\mathrm{SiO}_{2}$ and other major elements in the sediments of Yewa (Y) and Badagry (B) creeks

According to Li (2000), average basalt and average granite yield strongly contrasting ICV values of 2.20 and 0.95 . An interesting view of major element chemistry comes from a scatter plot of CIA against ICV values. To achieve this, the dataset generated on the studied sediments were compared with the rock class averages (Lee 2002). On the basis of this plot (Fig. 10), sediments from eastern and western Badagry creeks are mainly andesitic with very few indicating basaltic composition, whereas, sediments from Yewa Creek are overwhelmingly basaltic. The mafic composition indicated by sediments from Yewa Creek could have resulted from an overwhelming contribution of weathering products of the amphibolite and melanocratic components of gneisses in the area. Meanwhile, the discriminant plot of Roser \& Korsch (1988) employed, strongly inclined against an andesitic source for the sediments of Badagry (Fig. 11). However, the same discriminant plot reaffirmed the mafic igneous provenance for the sediments of Yewa Creek, implying differences in the composition of the source area. It is common to note that mafic igneous rocks are more susceptible to weathering and hence could have materials dominating the sediment, except where the addition of sea sands is influenced (i.e. the eastern end of Badagry Creek). 

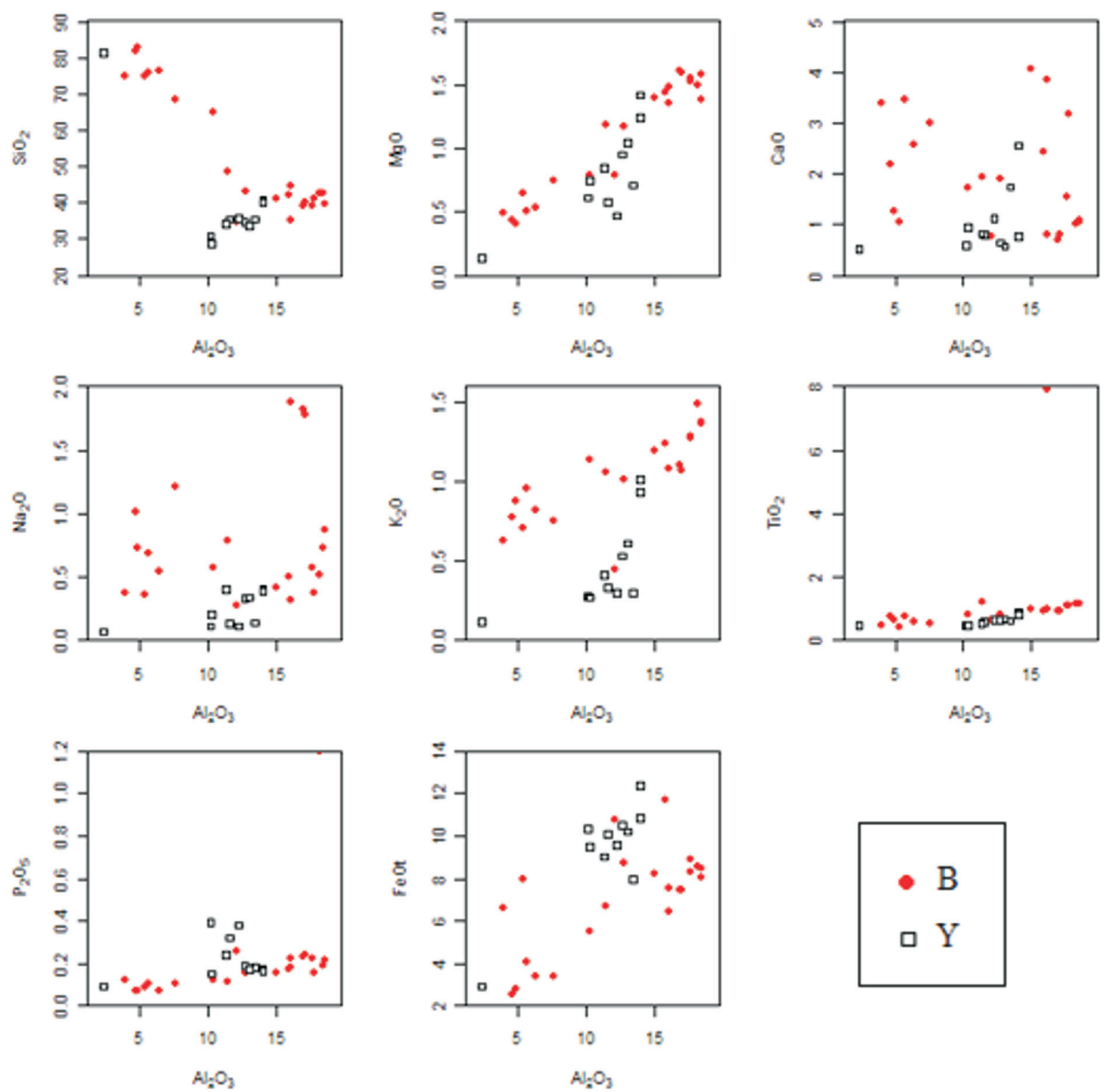

$\mathrm{Al}_{2} \mathrm{O}_{3}$

Fig. 7. Relationship between $\mathrm{Al}_{2} \mathrm{O}_{3}$ and other major elements in the sediments of Yewa (Y) and Badagry (B) creeks

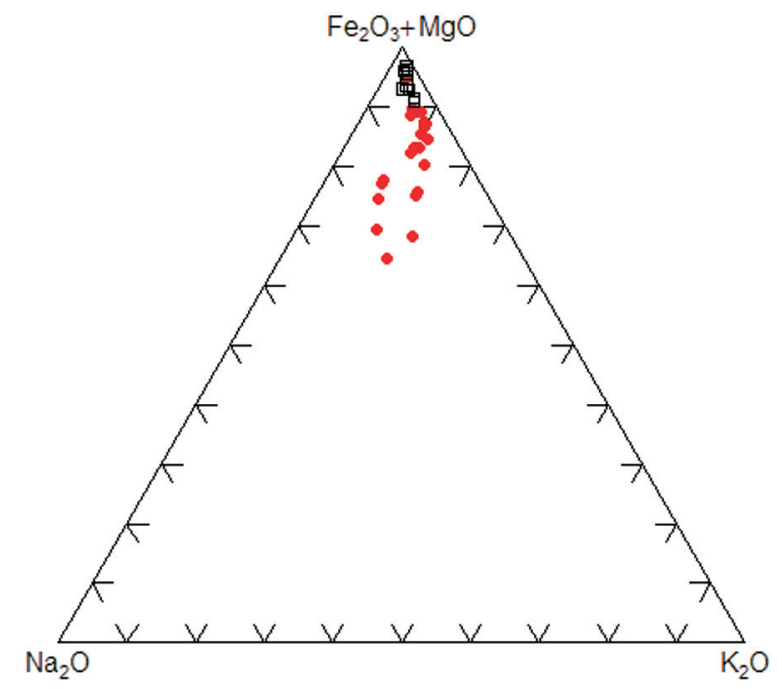

Fig. 8. $\left(\mathrm{Fe}_{2} \mathrm{O}_{3}+\mathrm{MgO}\right)-\mathrm{Na}_{2} \mathrm{O}-\mathrm{K}_{2} \mathrm{O}$ classification diagram for the sediments of Yewa and Badagry creeks (modified from Blatt et al. 1980)
The accumulation of certain trace metals in sediments may sometimes be determined by redox conditions through a change in redox state and or speciation (Mckay et al. 2007). The correlation between $\mathrm{Mn}$ and ferric iron is considered to interpret redox conditions since their ionic radii are comparable $(\mathrm{Fe}=61 \mathrm{pm}, \mathrm{Mn}=67 \mathrm{pm})$ they thus readily substitute for each other in minerals (Ure \& Berrow 1982). The ratio of $\mathrm{Mn}: \mathrm{Fe}\left(\mathrm{Mn}^{\star}\right)$ was calculated based on the Wedepohl (1978) formula:

$\mathrm{Mn}^{*}=\log \left[\left(\mathrm{Mn}_{\text {sample }} / \mathrm{Mn}_{\text {shale }}\right) /\left(\mathrm{Fe}_{\text {sample }} / \mathrm{Fe}_{\text {shale }}\right)\right]$,

where the values used for $\mathrm{Mn}_{\text {shale }}$ and $\mathrm{Fe}_{\text {shale }}$ are $600 \times 10^{-6}$ and $46150 \times 10^{-6}$ respectively. The ferric iron and manganese show contrasting ionic mobility across a redox boundary, while manganese 
tends to accumulate in more oxygenated conditions than iron (Bellanca et al. 1996). The negative values obtained from the calculated $\mathrm{Mn}^{\star}$ (from -0.14 to -0.41 ) indicate anoxic conditions for Yewa Creek except station Y10 (0.34) where

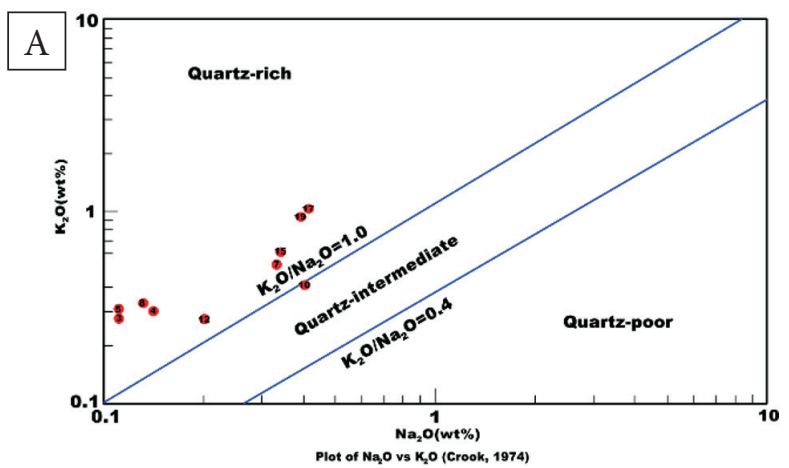

suboxic conditions (Tab. 3) were inferred. The western and eastern Badagry creeks may have had their sediments deposited under oxic to suboxic conditions arising from the overwhelming positive values of $\mathrm{Mn}^{*}$ in most stations.

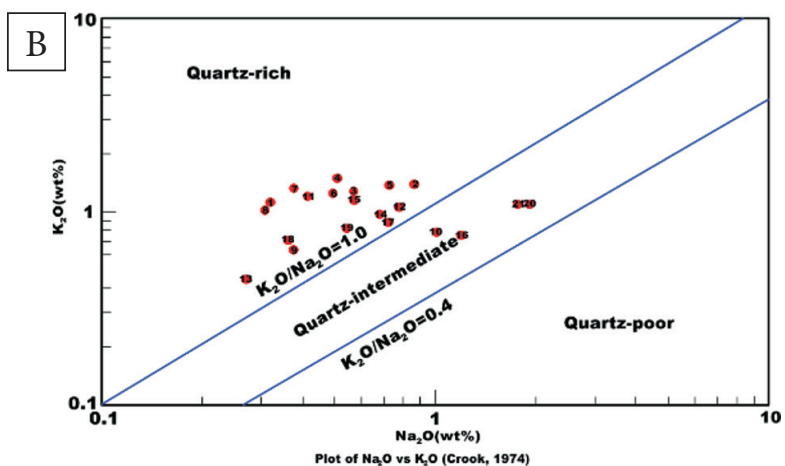

Fig. 9. Plot of $\mathrm{Na}_{2} \mathrm{O}$ versus $\mathrm{K}_{2} \mathrm{O}$ showing quartz enrichment in the sediments of Yewa (A) and Badagry (B) creeks

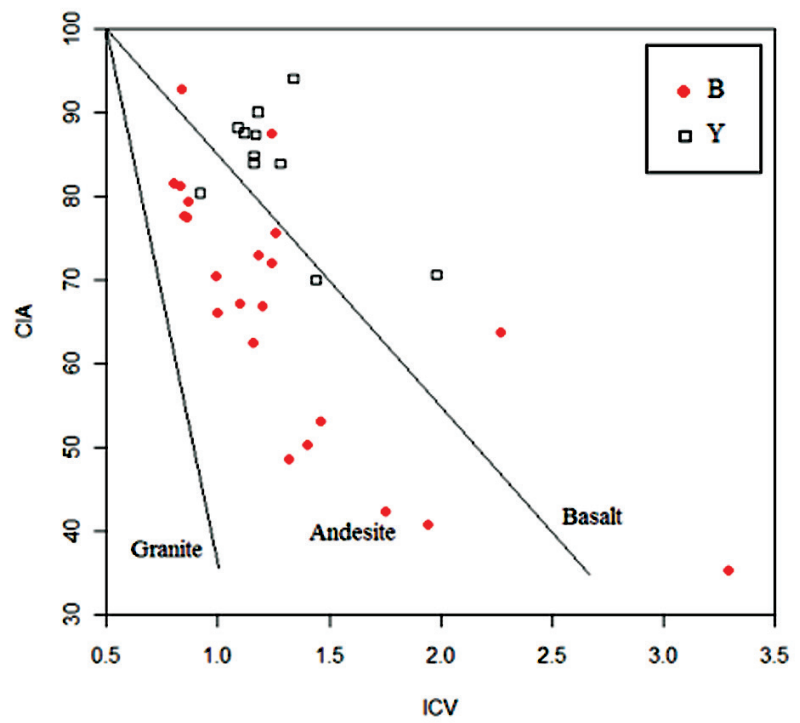

Fig. 10. Plot of chemical index of alteration (CIA) against index of compositional variability (ICV) for the sediments of Yewa and Badagry creeks (modified from Lee 2002)

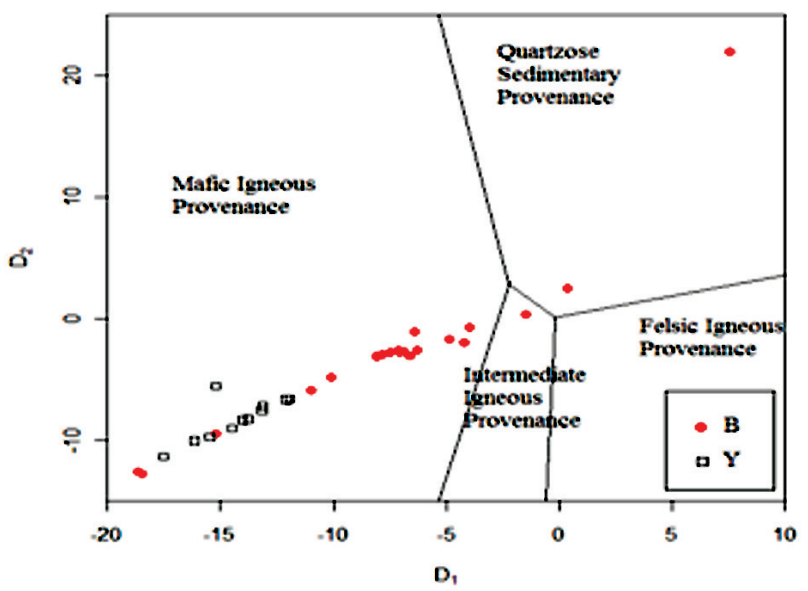

Fig. 11. Discriminant plot showing various provenance field boundaries for the studied sediments (adapted from Roser \& Korsch 1988) 


\section{Sediment sorting}

It is well known that transport and deposition of terrigenous clastic sediments involve hydraulic sorting. The effect on the chemical composition of these sediments is important (Bouchez et al. 2011b) and influence the distribution of paleo-weathering and provenance proxies (Bauluz et al. 2000, Le Pera et al. 2000). Also, the mechanical properties of host minerals determine the distribution of the chemical components within a suite. The mechanical sorting basically fractionates $\mathrm{Al}$ (clay minerals) from Si (quartz and feldspars, silt/sand sizes) as well as Ti in clay minerals and $\mathrm{Ti}$ oxides (fine silt sized) from $\mathrm{Zr}$ in zircon (coarse silt/fine sand). Ternary plots based on $\mathrm{Al}_{2} \mathrm{O}_{3}, \mathrm{TiO}_{2}$ and $\mathrm{Zr}$ should not reflect the weathering effects and may illustrate the presence of sorting-related fractionations recognizable by simple mixing trends on a ternary $\mathrm{Al}_{2} \mathrm{O}_{3}-\mathrm{TiO}_{2}-\mathrm{Zr}$ diagram (Garcia et al. 1994). In this study, a mixing trend, which may be consequent upon grain size sorting was large depicted by changes in the $\mathrm{Al}_{2} \mathrm{O}_{3} / \mathrm{Zr}$ ratio (Fig. 12).

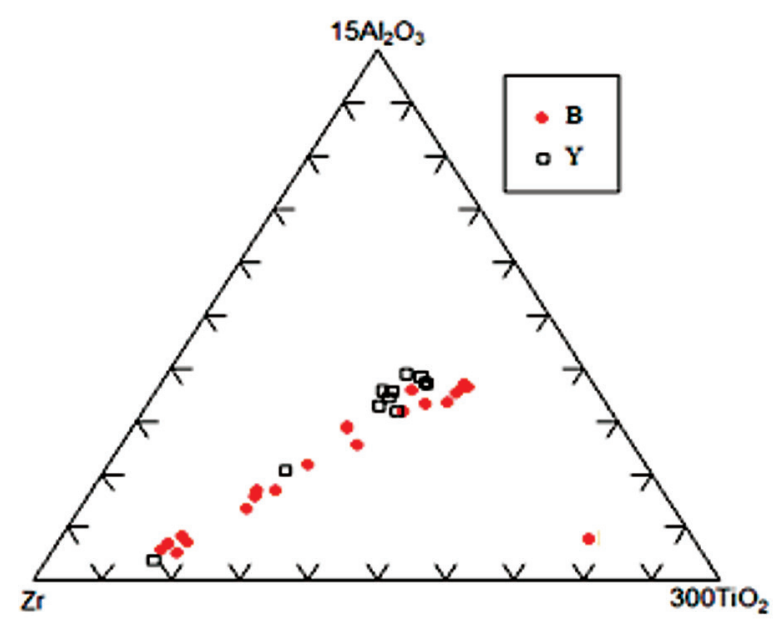

Fig. 12. Ternary plot of $15^{\star} \mathrm{Al}_{2} \mathrm{O}_{3}-\mathrm{Zr}-300^{\star} \mathrm{TiO}$, showing degree of sorting in the studied sediments (modified from Garcia et al. 1994)

The separation of the data set for the Yewa and Badagry creeks for correlation in fields of calc-alkaline granites (CAG) and strongly peraluminous granites (SPG) gave further clarification on the degree of sorting (Garcia et al. 1994). The resulting plot (Fig. 13A) interpreted the influence of sorting processes and provides information on the zircon concentration in sediment with a limited range of $\mathrm{TiO}_{2}-\mathrm{Zr}$, indicating low compositional maturity and insignificant sorting. However, this excludes most samples from the western end of Badagry Creek where relatively significant sorting was expounded. Sediments from Yewa creek are similar to those from the western end of Badagry Creek as they show moderate sorting (Fig. 13B).

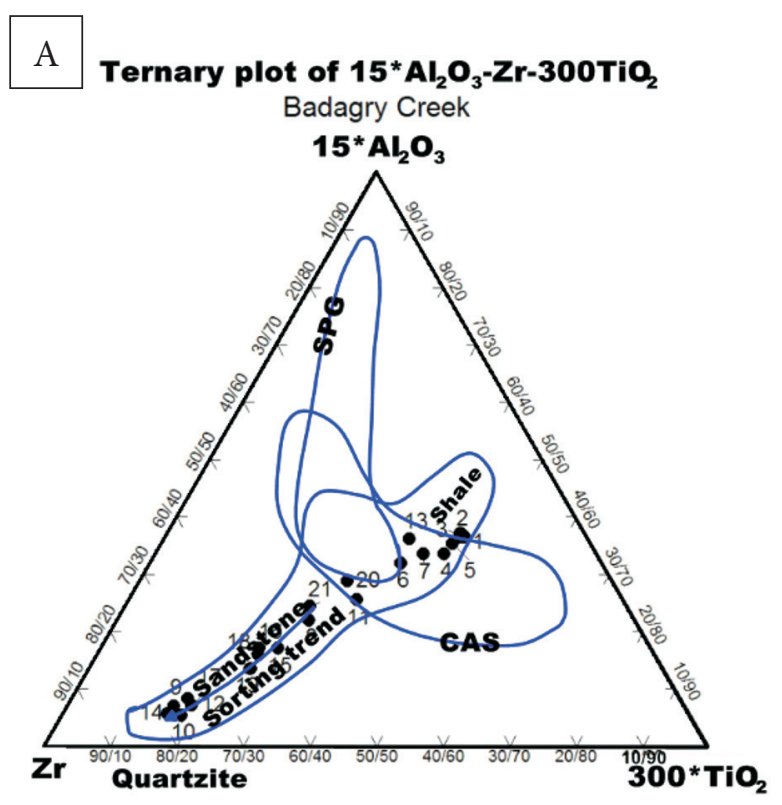

Ternary plot of Ternary plot of $15 * \mathrm{Al}_{2} \mathrm{O}_{3}-\mathrm{Zr}-300 \mathrm{TiO}$ (After Garciaet al, 1994)

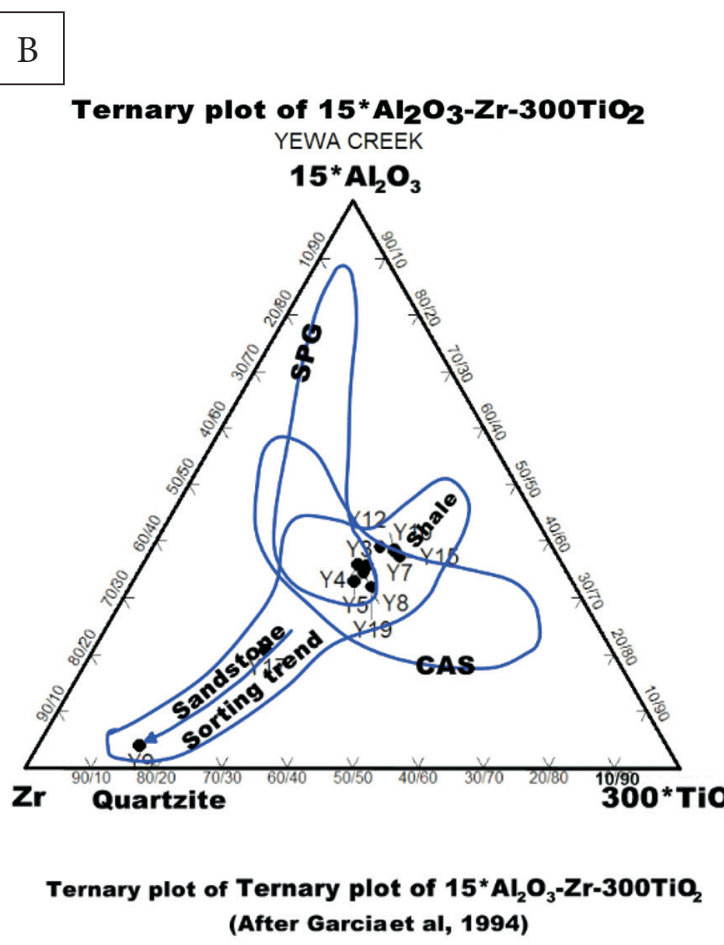

Fig. 13. Ternary plot showing sorting trends in fields of calcalkaline and strongly peraluminous granites for the sediments of Badagry (A) and Yewa (B) creeks 
The poor sorting trend characterising the sediments of the eastern end of Badagry Creek could be due to enrichment in sand-size components and deposition without recycling.

Based on the ICV values, $0.92-1.98$ and $0.85-$ 3.29 for the Yewa and the eastern end of Badagry creeks, respectively (Tab. 3), the sediments are interpreted to be compositionally immature to moderately mature and were likely to be dominated by first cycle input (values are mostly greater than unity). Conversely, ICV within $0.80-1.24$ was obtained for the sediments of the western end of Badagry Creek and about $63 \%$ of these values are lower than unity. This leaves no doubt that sediments from this creek are compositionally immature, although the closeness of ICV to 1.0 still affirms the first cycle input for sediments deposition (Cullers \& Podkovyrov 2000).

\section{Provenance}

Geochemical data and associated plots are very significant for relevant provenance demarcation (Keskin 2011). The abundance of Cr, Ni, Sc, and Th in clastic sediments can be considered a proxy in provenance studies. Also, the ratios $\mathrm{Al}_{2} \mathrm{O}_{3} / \mathrm{TiO}_{2}, \mathrm{TiO}_{2} / \mathrm{Zr}$; and scatter plots of $\mathrm{Th} / \mathrm{Sc}$ versus $\mathrm{Cr} / \mathrm{Sc}$; Th versus $\mathrm{Sc}$, $\mathrm{Y} / \mathrm{Ni}$ versus $\mathrm{Cr} / \mathrm{V}$ and $\mathrm{TiO}_{2}$ versus $\mathrm{Zr}$ are good indicators of provenance (Hiscott 1984, McLennan et al. 1990, Cullers 1994, Hayashi et al. 1997).

The $\mathrm{Al}_{2} \mathrm{O}_{3} / \mathrm{TiO}_{2}$ ratio of sediments range from 5.0-22.37 (Yewa Creek), 15.21-16.91 (the western end of Badagry Creek), and 2.01-19.50 (the eastern end of Badagry Creek). These values strongly infer basic to intermediate igneous source rocks (Paikaray et al. 2008). Based on Hayashi et al. (1997), the $\mathrm{TiO}_{2}$ versus $\mathrm{Zr}$ plot for the investigated sediments depicts dominance of intermediate igneous source for Yewa Creek (Fig. 14A). The sediments of the western end of Badagry Creek are mainly sourced from mafic rocks whereas the sediments of the eastern end of Badagry Creek are linked to intermediate and felsic igneous progenitors (Fig. 14B). Trace element datasets of sediments from the investigated creeks were plotted on a Sc-Th scatter plot in three fields (Fig. 15). The fields are characterized by $\mathrm{Th} / \mathrm{Sc}$ ratios $\geq 1.0$ typical for continental crust enriched in incompatible elements $\geq 0.6-1.0$ for andesitic composition; and $<0.6$ typifying mafic signature.

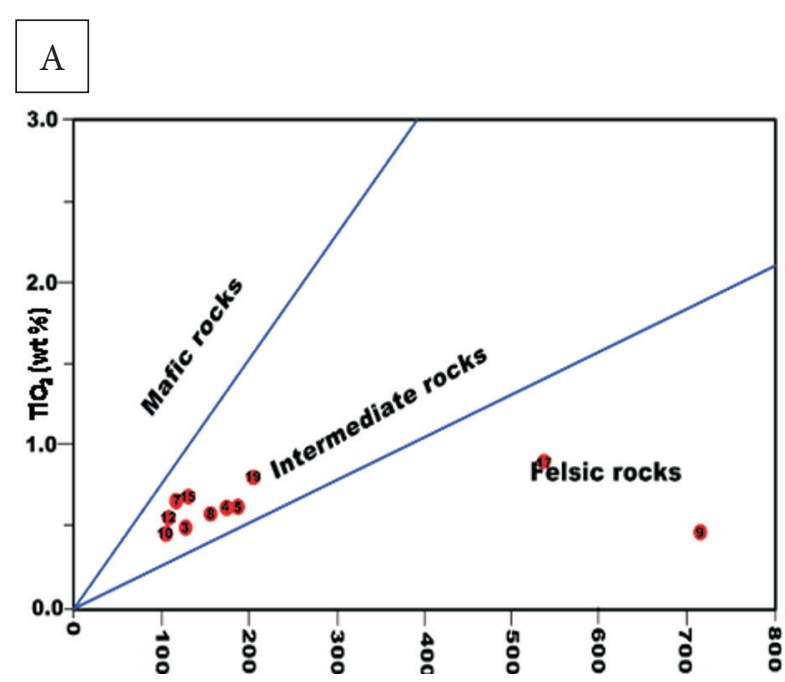

B

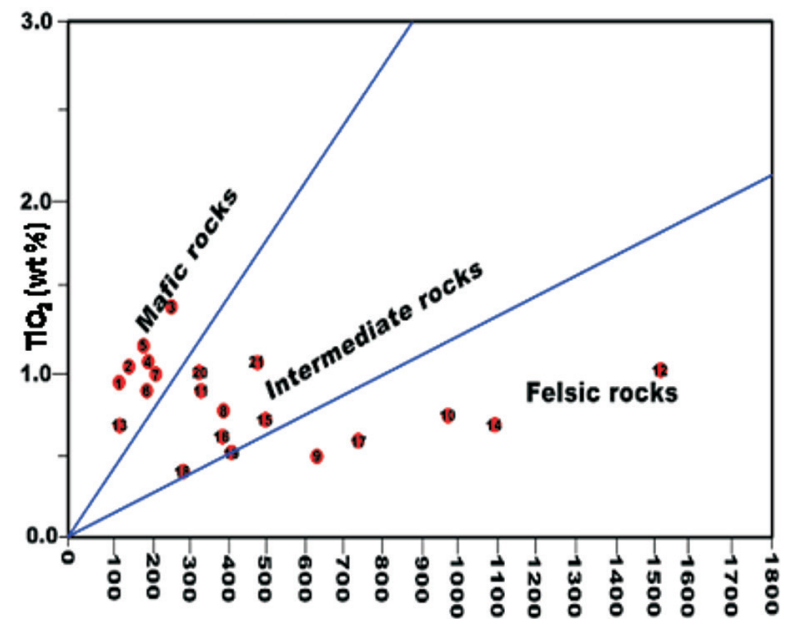

Fig. 14. $\mathrm{TiO}_{2}-\mathrm{Zr}$ plot for Yewa (A) and Badagry (B) creeks (Hayashi et al. 1997)

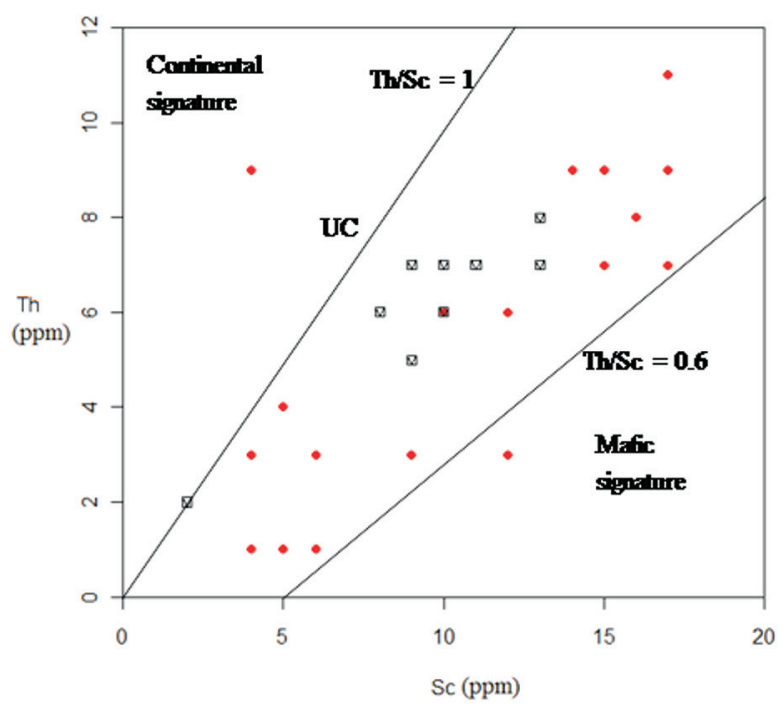

Fig. 15. The scattered plot of Th against Sc for the sediments of Yewa and Badagry creeks 
It is consequential to note that almost all the samples plotted within the field of an intermediate igneous progenitor implying that the sediments of the creeks are equally enriched in Th and Sc. The scatter plots of $\mathrm{Y} / \mathrm{Ni}$ versus $\mathrm{Cr} / \mathrm{V}$ ratios (Fig. 16) have also been used to complement the discrimination of source area (Hiscott 1984). Here $\mathrm{Cr} / \mathrm{V}$ ratios serve as an index of the enrichment of $\mathrm{Cr}$ over other ferromagnesian trace elements, whereas $\mathrm{Y} / \mathrm{Ni}$ monitors the general level of proxy for heavy rare earth elements (HREE) i.e. Y compared with ferromagnesian trace element $(\mathrm{Ni})$. The mafic to ultramafic sources tend to contain higher $\mathrm{Cr} / \mathrm{V}$ and lower $\mathrm{Y} / \mathrm{Ni}$ ratios. Almost all the samples from the creeks are characterized by very low $\mathrm{Cr} / \mathrm{V}$ ratio $(<2.0)$ inferring abundance of felsic components. Also, the overwhelming majority of these samples have neither very low $\mathrm{Y} / \mathrm{Ni}$ ratio to infer the dominance of mafic constituents nor a high ratio to infer an abundance of felsic materials $(>0.6-1.8)$. This may indicate that the both upper and lower crustal compositions are represented in the source area (andesitic).

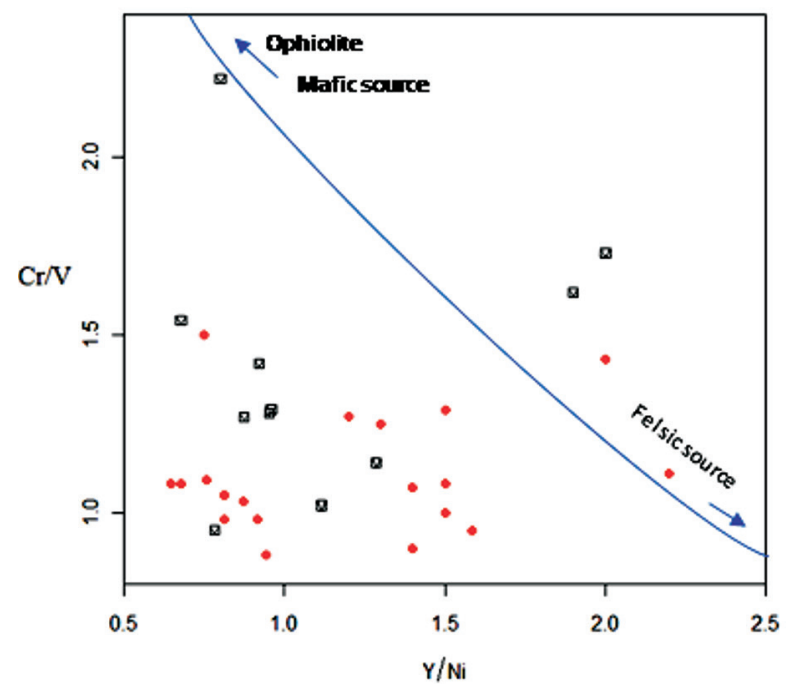

Fig. 16. $\mathrm{Cr} / \mathrm{V}$ versus $\mathrm{Y} / \mathrm{Ni}$ diagram. Curve model mixing between mafic and felsic end members

\section{Weathering intensity}

The chemical composition of detrital sediments depends on source area composition, weathering, sorting; and in ancient sediments the depth and history of burial must be included. Among these factors, source area composition, weathering and sorting are of relevance to the present study.
Weathering which is yet to be considered is specifically emphasized in this section. The most widely used chemical index to determine the degree of source rock weathering is the chemical index of alteration (CIA). This index takes assumption that $\mathrm{Ca}, \mathrm{Na}$ and $\mathrm{K}$ decrease as the duration and/or intensity of weathering increases (Duzgorein-Aydin et al. 2002). CIA values for the western Badagry and Yewa creeks range from 66.10 to 92.80 (mean value 77.06 ) and 70.0 to 94.0 (average 83.75) respectively. The average values are typical of moderate and extreme chemical weathering (Fedo et al. 1995). The CIA for the western end of Badagry Creek reflects the presence of muscovite, illite and smectile, whereas the values for the sediments of Yewa Creek are indicative of clays enriched in kaolinite and aluminium-oxy-hydroxides. The sediments of the hydrographically complex eastern end of Badagry Creek have shown a wide variation in CIA values from 35.0 to 87.5 with average value of 60.63 , indicating incipient chemical weathering. Of importance are areas with weathered source materials (B9, B10 and B14) and high intensity of chemical weathering (B13) at the eastern end of Badagry Creek.

The degree of chemical weathering can also be estimated using the plagioclase index of alteration (PIA) suggested by Fedo et al. (1995). This is a measure of rate of conversion of plagioclase feldspar in siliciclastic sediments to clay minerals. Chemically unaltered plagioclase has a PIA value of 50 or less, intensity of plagioclase conversion increases to 100 , the point at which it is believed all the feldspar has been converted to clay minerals. The sediments of the Yewa and western Badagry creeks are composed of moderately to intensely weathered plagioclase feldspar on the basis of PIA values ranging from 72.4 to 96.7 and from 67.8 to 99.3 respectively The PIA values for the sediments of the eastern end of Badagry Creek vary from 33.2 to 90.3 . The implication is that there are locations with no significant alteration of plagioclase, although fewer than areas marked with moderate to intensely weathered plagioclase (Tab. 3).

Generally, the values of ICV decrease with an increasing degree of weathering. Sediments with the same degree of weathering based on CIA and PIA may have a different ICV which reflects differences in the composition of the source area. 
According to Fedo et al. (1995), ICV decreases from $>10$ for non-clay silicate minerals such as pyroxene and amphiboles to $0.8-1.0$ (alkali feldspars), $\simeq 0.15-0.3$ (Montmorrilonite group), and $\simeq 0.03-0.05$ (kaolinite group). As mentioned earlier, the studied sediments are characterized by ICV values in the ranges of $0.92-1.98,0.80-1.24$ and 0.85-3.29 for the Yewa, western and eastern Badagry creeks respectively. This implies that, in spite of high CIA and PIA, expected corresponding low values of ICV were not obtained (Tab. 3). However, inferring from the calculated values of ICV, the sediments of these creeks seem to be composed of alkali feldspars and non-clay silicate minerals (Weaver 1989). This strongly contrasts with the moderate to high intensity of chemical weathering inferred earlier. To further probe the interpretation of ICV on the dominance of alkali feldspars and non-clay silicate minerals, the ratio of $\mathrm{K}_{2} \mathrm{O}$ / $\mathrm{Al}_{2} \mathrm{O}_{3}$ was employed (Cox et al. 1995). This ratio furnishes information on how much alkali feldspars versus plagioclase and clay minerals are present. It is believed that $\mathrm{K}_{2} \mathrm{O} / \mathrm{Al}_{2} \mathrm{O}_{3}$ ratio decreases from alkali feldspars $(\simeq 0.4-1.0)$, illite $(\simeq 0.3)$ to other clay minerals $(\simeq 0)$. Substantially, the ratios $\mathrm{K}_{2} \mathrm{O} / \mathrm{Al}_{2} \mathrm{O}_{3}$ complement the inferences drawn from CIA and PIA based on values ranging from $0.08-0.6($ mean $=0.28), 0.08-0.84($ mean $=0.37)$ and 0.11-2.56 (mean $=0.75$ ) for sediments of the Yewa, western and eastern Badagry creeks respectively. The sediments of the Yewa Creek, are therefore, composed of mainly illite-smectite and other clay mineral group. In a relative manner, sediments are largely composed of alkali feldspars and the illite group at the western end of Badagry Creek; and significant alkali feldspars characterised the eastern end of Badagry Creek.

In the A-CN-K $\left(\mathrm{Al}_{2} \mathrm{O}_{3}-\mathrm{CaO}+\mathrm{Na}-\mathrm{K}_{2} \mathrm{O}\right)$ diagram proposed to interpret the trends and degree of silicate weathering and evaluate the parent rock composition, most samples were plotted along the A-CN above plagioclase-k-feldspar tie line (Fig. 17). The implication is that there is preferential leaching of $\mathrm{CaO}$ and $\mathrm{Na}_{2} \mathrm{O}$ over $\mathrm{K}_{2} \mathrm{O}$, and relative enrichment of $\mathrm{Al}_{2} \mathrm{O}_{3}$. This may be consequent upon the more susceptible plagioclase giving up $\mathrm{Na}$ and $\mathrm{Ca}$ relative to $\mathrm{K}$ from orthoclase feldspar which remain less displaced. On the basis of A-C-M $\left(\mathrm{Al}_{2} \mathrm{O}_{3}-\mathrm{CaO}-\mathrm{Fe}_{2} \mathrm{O}_{3}+\mathrm{MgO}\right)$ ternary plot
(Fig. 18), ferromagnesian minerals seemed to have undergone alteration thereby relinquishing soluble cations in solution, giving room for the enrichment of alumina rich minerals (gibbsite and/or illite). This is evident in most locations at the Yewa and western Badagry creeks, and can be illustrated as indicated by equation:

$$
\begin{aligned}
& \mathrm{KMgFe}_{2} \mathrm{AlSi}_{3} \mathrm{O}_{10}(\mathrm{OH})_{2}+\mathrm{Al}(\mathrm{OH})_{3}+2 \mathrm{Fe}(\mathrm{OH})_{3}+ \\
& +1 / 2 \mathrm{O}_{2}+3 \mathrm{CO}_{2}+\rightarrow+\mathrm{K}^{+}+\mathrm{Mg}^{2+}+ \\
& +11 \mathrm{H}_{2} \mathrm{O}+3 \mathrm{HCO}_{3}^{-}+3 \mathrm{H}_{4} \mathrm{SiO}_{4} \\
& \text { biotite gibbsite }
\end{aligned}
$$

Most samples of the eastern end of Badagry Creek plotted parallel to the A-C line implying dissociation of calcium from plagioclase for moderate enrichment in alumina to yield smectite-illite.

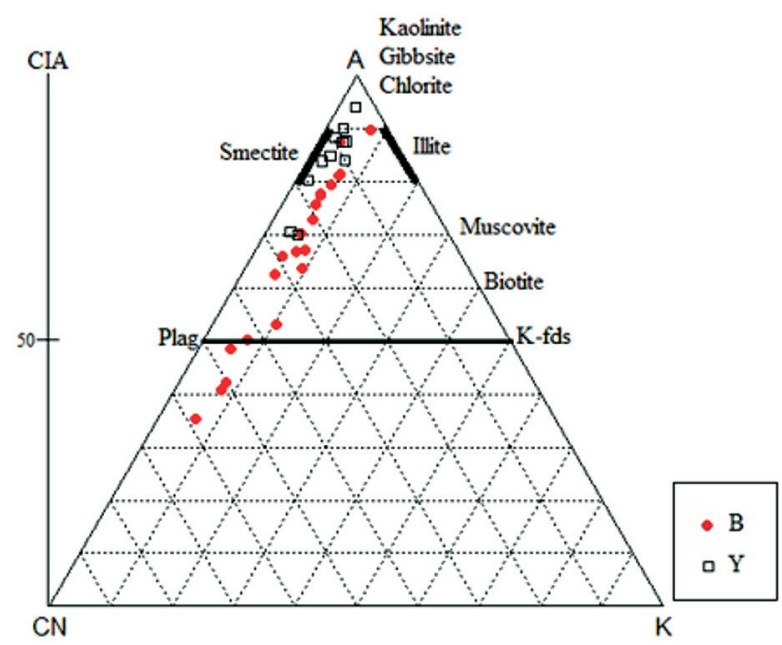

Fig. 17. The A-CN-K diagram for the sediments of Yewa and Badagry creeks

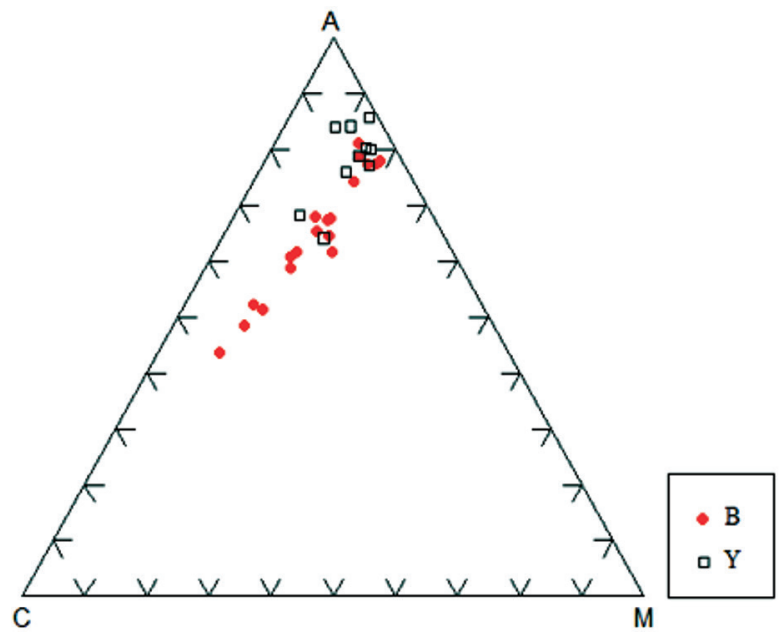

Fig. 18. A-C-M diagram for the sediments of Yewa and Badagry creeks 


\section{CONCLUSIONS}

Major elements are most useful for estimating the degree of weathering of source sediments, whereas trace elements are best suited for the appraisal of relative proportions of mafic and felsic rocks in the sediment source area. The Yewa and western Badagry creeks characterised by mud-dominated sediments, have higher than average concentrations of $\mathrm{Ni}, \mathrm{Sr}, \mathrm{Y}, \mathrm{Nb}, \mathrm{Sc}, \mathrm{Zr}, \mathrm{Co}, \mathrm{V}$, and Th than the eastern end of Badagry Creek where the quantity of sand is significantly high. Except for $\mathrm{CaO}$ and $\mathrm{Na}_{2} \mathrm{O}$ which possessed a scattered distribution due to outliers, the behaviour of major oxides showed linear negative trends with $\mathrm{SiO}_{2}$ for sediments of the entire Badagry Creek. However, these oxides exhibited positive linear trends with $\mathrm{Al}_{2} \mathrm{O}_{3}$ suggesting major influences of hydraulic fractionation. On the basis of $\mathrm{Na}_{2} \mathrm{O}, \mathrm{K}_{2} \mathrm{O}, \mathrm{Fe}_{2} \mathrm{O}_{3}$, and $\mathrm{MgO}$ contents, the investigated sediments have been classified as lithic arenite; and the binary plot of $\mathrm{Na}_{2} \mathrm{O}-\mathrm{K}_{2} \mathrm{O}$ showed that sediments are rich in quartz. The major element dataset was used to generate a scatter plot of CIA against ICV and compared with rock class averages. This plot revealed that the sediments from the two segments of Badagry Creek are principally andesitic, whereas a mafic igneous signature was discerned for Yewa Creek.

Except for most samples from the western end of Badagry Creek, where relatively significant sorting was expounded, the plot of $\mathrm{Al}_{2} \mathrm{O}_{3}-\mathrm{Ti}_{2} \mathrm{O}-\mathrm{Zr}$ interpreted a low compositional maturity and insignificant sorting for all sediments. Also, the calculated ICV values complemented low compositional maturity and the first cycle input for sediments deposition. The $\mathrm{Al}_{2} \mathrm{O}_{3} / \mathrm{TiO}_{2}, \mathrm{TiO}_{2} / \mathrm{Zr}$ ratios and scatter plots of $\mathrm{Th} / \mathrm{Sc}$ versus $\mathrm{Cr} / \mathrm{Sc}$; Th versus $\mathrm{Sc}, \mathrm{Y} / \mathrm{Ni}$ versus $\mathrm{Cr} / \mathrm{V}$ and $\mathrm{TiO}_{2}$ versus $\mathrm{Zr}$, which are good indicators of provenance, revealed the dominance of andesitic materials in the studied sediments. Although the average composition of source sediments at the eastern end of Badagry Creek is andesitic, the quantity of felsic components is highly remarkable. Also, it is equally important to document the significant proportion of mafic components in the sediments of the Yewa and western Badagry creeks.
CIA and PIA indices suggest that weathering in the catchments of Yewa and western Badagry Creeks was moderate to intense; and the eastern end of Badagry Creek was marked by incipient weathering, probably due to relatively high erosion rates.

\section{REFERENCES}

Adegoke O.S., Jeje L.K., Durotoye B., Adeleye A. \& Ebukanson E.E., 1980. The Geomorphology and aspects of sedimentology of coastal region of Western Nigeria. Journal of Mining and Geology, 17, 217-223.

Balashov Yu.A., Ronov A.B., Migdisova A., Turanskaya N.V., 1964. Vliyaniye klimaticheskikh ifatsial'nykh usloviy na razdeleniye redkozemel'nykh elementov $\mathrm{v}$ osadochnom protses. Geokhimiya, 10, 995-1014 [Балашов Ю.А., Ронов А.Б., Мигдисов А.А., Туранская Н.В., 1964. Влияние климатических и фациальных условий на разделение редкоземельных элементов в осадочном процессе. Геохимия, 10, 995-1014].

Bauluz B., Mayayo M.J., Fernandez-Nieto C. \& Lopez J.M.G., 2000. Geochemistry of Precambrian and Paleozoic siliciclastic rocks from the Iberian Range (NE Spain): implications for source-area weathering, sorting, provenance, and tectonic setting. Chemical Geology, 168, 135-150.

Bellanca A., Claps M., Erba E., Masetti D., Neri R., Premolisilva I. \& Venezia F., 1996. Orbitally induced limestone/marlstone rhythms in the Albian-Cenomanian Cismon section (Venetian region, northern Italy): Sedimentology, calcareous and siliceous plankton distribution, elemental and isotope geochemistry. Paleogeography, Paleoclimatology and Paleoecology, 126, 227-260.

Berner R.A. \& Berrow E.K., 1997. Silicate weathering and climate. [in:] Ruddiman W.F. (ed.), Tectonic Uplift and Climate Change, Plenum, New York, 353-365.

Blatt H., Middleton G. \& Murray R., 1980. Origin of Sedimentary Rocks. Prentice-Hall, New Jersey.

Bouchez J., Lupker M., Gaillardet J., France-Lanord C. \& Maurice L., 2011a. How important is it to integrate riverine suspended sediment chemical composition with depth? Clues from Amazon River depth-profiles. Geochimica et Cosmochimica Acta, 75, 6955-6970.

Bouchez J., Gaillardet J., France-Lanord C., Maurice L. \& Dutra-Maia, P., 2011b. Grain size control of river sediment geochemistry: Clues from Amazon River depth profiles. Geochemistry Geophysics Geosystems, 12, 1-24.

Cox R., Lowe D.R. \& Cullers R.L., 1995. The influence of sediment recycling and basement composition on evolution of mudrock chemistry in the southwestern United States. Geochimica et Cosmochimica Acta, 59, 2919-2940.

Crook K.A.W., 1974. Lithogenesis and geotectonics: The significance of compositional variation in flysch arenites (greywackes). Society of Economical, Paleontological and Mineralogical Special Publications, 19, 304-310.

Cullers R.L., 1994. The controls on the major and trace element variation of shales, siltstones and sandstones of Pennsylvanian-Permian age from uplifted continental blocks in Colorado to platform sediments in Kansas, USA. Geochimica et Cosmochimica Acta, 58, 4955-4972. 
Cullers R.L. \& Podkovyrov V.N., 2000. Geochemistry of the Mesoproterozoic Lakhanda shales in southeastern Yakutia, Russia: implications for mineralogical and provenance control, and recycling. Precambrian Research, $104,77-93$.

Cullers R.L., Yeh L.T., Chaudhuri S. \& Guidotti C.V., 1974. Rare earth elements in Silurian pelitic schists from NW Maine. Geochimica et Cosmochimica Acta, 38, 389-400.

Davies B.E., 1980. Applied Soil Trace Elements. New York, Wiley.

Dickinson W. R. \& Suczek C.A., 1979. Plate tectonics and sandstone compositions. AAPG Bulletin, 63, 2164-2182.

Dickinson W.R., 1985. Interpreting provenance relations from detrital modes of sandstones. [in:] Zuffia G.G. (ed.), Provenance of Arenites, Dordrecht, Reidel, 333-362.

Duzgoren-Aydin N.S., Aydin A. \& Malpas J., 2002. Re-assessment of chemical weathering indices: case study on pyroclastic rocks of Hong Kong. Engineering Geology, $63,99-119$.

Edmond J.M. \& Huh Y., 1997. Chemical weathering yields from basement and orogenic terrains in hot and cold climates. [in:] Ruddiman W.F. (ed.), Tectonic Uplift and Climate Change, Plenum, New York, 353-365.

Faure G., 1991. Principles and Applications of Inorganic Geochemistry. Macmillan, New York.

Fedo C.M., Nesbitt H.W. \& Young G.M., 1995. Unraveling the effects of potassium metasomatism in sedimentary rocks and paleosols, with implications for paleo-weathering conditions and provenance. Geology, 23, 921-924.

Folk R.L., 1954. The distinction between grain size and mineral composition in sedimentary-rock nomenclature. The Journal of Geology, 62, 344-359.

Gale J.G. \& Hoare P.G., 1991. The physical composition and analysis of regolith materials. [in:] Quaternary Sediments: Petrographic Methods for the Study of Unlithified Rocks, Belhaven Press, New York, 87-94.

Garcia D., Fonteilles M. \& Moutte J., 1994. Sedimentary fractionation between $\mathrm{Al}, \mathrm{Ti}$, and $\mathrm{Zr}$ and genesis of strongly peraluminous granites. Journal of Geology, 102, 411-422.

Garrels R.M. \& Mackenzie F.T., 1971. Evolution of sedimentary rocks. Norton, New York.

Grygar, T.M. \& Popelka, J., 2016. Revisiting geochemical methods of distinguishing natural concentrations and pollution by risk elements in fluvial sediments. Journal of Geochemical Exploration, 170, 39-57.

Hayashi K.I., Fujisawa H., Holland H.D. \& Ohmoto H., 1997. Geochemistry of $\sim 1.9$ Ga sedimentary rocks from northeastern Labrador, Canada. Geochimica et Cosmochimica Acta, 61, 4115-4137.

Hiscott R.N., 1984. Ophiolitic source rocks for Taconic-Age flysch: trace-element evidence. Geologic Society of America Bulletin, 95, 1261-1267.

Ibe A.C.,1988. Coastline erosion in Nigeria. Ibadan University Press, Ibadan, Nigeria.

Keskin S., 2011. Geochemistry of Çamardı Formation sediments, central Anatolia (Turkey): implication of source area weathering, provenance, and tectonic setting. Geosciences Journal, 15, 185-195.

Lasaga A.C., 1984. Chemical kinetics of water-rock interactions. Journal of geophysical research: solid earth, 89(B6), 4009-4025.
Le Pera E.M.I.L.I.A. \& Sorriso-Valvo M., 2000. Weathering, erosion and sediment composition in a high-gradient river, Calabria, Italy. Earth Surface Processes and Landforms, 25, 277-292.

Lee Y.I., 2002. Provenance derived from the geochemistry of late Paleozoic-early Mesozoic mudrocks of the Pyeongan Supergroup, Korea. Sedimentary Geology 149, 219235.

Li Y.H., 2000. A compendium of Geochemistry. Princeton University Press, Princeton, NJ.

Mack G.H., 1978. The survivability of labile light-mineral grains in fluvial, aeolian and littoral marine environments: the Permian Cutler and Cedar Mesa Formations, Moab, Utah. Sedimentology, 25, 587-604.

McKay J.L., Pedersen T.F. \& Mucci A., 2007. Sedimentary redox conditions in continental margin sediments (N.E. Pacific) - Influence on the accumulation of redox-sensitive trace metals. Chemical Geology, 238, 180-196.

McLennan S.M., 1989. Rare earth elements in sedimentary rocks; influence of provenance and sedimentary processes. Reviews in Mineralogy and Geochemistry, 21, 169-200.

McLennan S.M., 1993. Weathering and global denudation. The Journal of Geology, 101, 295-303.

McLennan S.M., Taylor S.R., McCulloch M.T. \& Maynard J.B., 1990. Geochemical and Nd- Sr isotopic composition of deep-sea turbidites: crustal evolution and plate tectonic associations. Geochimica et Cosmochimica Acta, 54, 2015-2050.

Nesbitt H.W., 1979. Mobility and fractionation of rare earth elements during weathering of a granodiorite. Nature, 29, 206-210.

Nesbitt H.W. \& Young G.M., 1984. Prediction of some weathering trends of plutonic and volcanic rocks based on thermodynamic and kinetic considerations. Geochimica et Cosmochimica Acta, 48, 1523-1534.

Oliva P., Viers J. \& Dupré B., 2003. Chemical weathering in granitic environments. Chemical Geology, 202, 225-256.

Paikaray S., Banerjee S. \& Mukherji S., 2008. Geochemistry of shales from the Paleoproterozoic to Neoproterozoic Vindhyan Supergroup: Implications on provenance, tectonics and paleoweathering. Journal of Asian Earth Sciences, 32, 34-48.

Phillips, O. A. \& Falana, A. O., 2008. Mineralogical - Petrological study of rocks in Olode Area, Ibadan, Southwestern Nigeria. The Scientific Society of Mineral Wealth of Greece, 146, 25-35.

Phillips, O.A., Adebayo, A.J. \& Falana, A.O., 2013. Petrogenesis of Pan-African Gneisses around Obalarinnako-Oyo area, southwestern Nigeria. Science Focus, 18, 78-95.

Roser B.P. \& Korsch R.J., 1988. Provenance signatures of sandstone-mudstone suites determined using discriminant function analysis of major-element data. Chemical Geology, 67, 119-139.

Shepard F.P., 1954. Nomenclature based on sand-silt-clay ratios. Journal of Sedimentary Research, 24, 3, 151-158.

Singh P. \& Rajamani V., 2001. REE geochemistry of recent clastic sediments from the Kaveri floodplains, southern India: implication to source area weathering and sedimentary processes. Geochimica et Cosmochimica Acta, 65, 3093-3108. 
Talabi A.O., 2013. Mineralogical and chemical characterization of major basement rocks in Ekiti State, SW-Nigeria. $R M Z-M \& G, 60,73-86$.

Taylor S.R. \& McLennan S.M., 1985. The continental crust: its composition and evolution. Blackwell Scientific Publishing, Oxford.

Tripathi J.K. \& Rajamani V., 1999. Geochemistry of the loessic sediments on Delhi ridge, eastern Thar desert, Rajasthan: implications for exogenic processes. Chemical Geology, 155, 265-278.

Tripathi J.K. \& Rajamani V., 2007. Geochemistry and origin of ferruginous nodules in weathered granodioritic gneisses, Mysore Plateau, Southern India. Geochimica et Cosmochimica Acta, 71, 1674-1688.

Ure A.M. \& Berrow M.L., 1982. The elemental constituents of soils. [in:] Bowen H.J.M. Environmental chemistry.
Volume 2, Specialist Periodical Reports, Royal Society of Chemistry, London, 94-204.

Viers J., Dupré B. \& Gaillardet J., 2009. Chemical composition of suspended sediments in World Rivers: new insights from a new database. Science of the total Environment, 407, 853-868.

Weaver C.E., 1989. Clays, muds, and shales. Development in Sedimentology, 44, Amsterdam, Elsevier.

Wedepohl K.H., 1978. Manganese: Abundance in common sediments and sedimentary rocks. [in:] Wedepohl K.H. (ed.), Handbook of Geochemistry, 113, Springer Berlin, $1-17$.

Yang S., Jung H.S. \& Li C.X., 2004. Two unique weathering regimes in the Changjiang and Huanghe drainage basins: geochemical evidence from river sediments. Sedimentary Geology, 164, 19-34. 